\title{
Temperature impact on reproduction and development of congener copepod populations
}

\author{
Claudia Halsband-Lenk ${ }^{\mathrm{a}, \mathrm{b}, *}$, Hans-Jürgen Hirche ${ }^{\mathrm{a}}$, \\ François Carlotti ${ }^{\mathrm{b}, 1}$ \\ alfred-Wegener-Institute for Polar and Marine Research, Columbusstrasse, 27568 Bremerhaven, Germany \\ ${ }^{\mathrm{b}}$ LOBEPM Station Zoologique, B.P. 28, 06234 Villefranche-sur-Mer Cedex, France
}

Received 31 July 2001; received in revised form 20 January 2002; accepted 24 January 2002

\begin{abstract}
The goal of this study was to relate the temperature response of all developmental stages and reproductive biology of two congener copepod pairs inhabiting different biogeographic regions to their geographic distribution patterns. Survival of adult females and egg production, embryonic development and hatching success of the genera Centropages and Temora from two stations, in the North Sea and the Mediterranean, were studied in laboratory experiments in a temperature range from 2 to $35^{\circ} \mathrm{C}$. Postembryonic development was determined from cohorts raised at temperatures between 10 and $20{ }^{\circ} \mathrm{C}$ with surplus food. Tolerance limits and optima of female survival, reproduction and development distinguished the northern species Centropages hamatus and Temora longicornis from the southern T. stylifera, while C. typicus, which is found in both regions, was intermediate. Thus, thermal preferences could in part explain distribution patterns of these species. While C. hamatus and the two Temora species showed distinct temperature ranges, C. typicus was able to tolerate different temperature conditions, resulting in its wide distribution range from the subarctic to the tropics. However, the thermal range of a species did not necessarily correlate with the optimal temperatures in the experiments. Optima of egg production and stage development were surprisingly low in $T$. stylifera, which has a mere southern distribution. (C) 2002 Elsevier Science B.V. All rights reserved.
\end{abstract}

Keywords: Centropages; Development; Distribution; Reproduction; Temora; Temperature response

\footnotetext{
* Corresponding author. Present address: Institut für Hydrobiologie und Fischereiwissenschaft, Zeiseweg 9, 22765 Hamburg, Germany. Tel.: +49-40-42838-6685; fax: +49-40-42838-6696.

E-mail address: claudia.halsband@uni-hamburg.de (C. Halsband-Lenk).

${ }^{1}$ Present address: Laboratoire d'Océanographie Biologique, 2 rue du Professor Jolyet, 33120 Arcachon, France.
} 


\section{Introduction}

Biogeography has raised interest recently within the context of biodiversity and climate change. While there exists a large body of literature on geographic distributions, little is known on the factors controlling it (Pörtner, 2001). Congener pairs appear most appropriate to study tolerance limits and optima of life history traits with regard to their significance for distribution patterns, as they are morphologically very similar.

Distribution patterns of congener copepod species often differ considerably either on a spatial or temporal scale. Spatial separation of species can occur (1) horizontally, e.g. by geographical latitudes (Conover, 1988; Jashnov, 1970) or hydrographic features (Planque and Fromentin, 1996) as shown for Calanus sp., (2) vertically like in Calanus and Euchaeta congeners (Williams, 1985; Roe, 1972), or (3) by topographic regions, e.g. shelf or off shore areas, observed for Centropages species (Grant, 1988). Temporal separation of species is observed as seasonal succession, like in Acartia tonsa and A. hudsonica (Sullivan and McManus, 1986).

In our study, we focused on pairs of Centropages (Centropages typicus and $C$. hamatus) and Temora (Temora longicornis and T. stylifera) congeners (Copepoda: Calanoida) occurring in the North Sea and the Mediterranean. These free-spawning species belong on the one hand to a boreal, cold-temperate community ( $C$. hamatus, $T$. longicornis), while T. stylifera on the other hand is a southern, warm-temperate species. $C$. typicus is regarded as a common constituent of both the warm and the northern cold plankton and therefore is called a "southern intermediate form" (Colebrook, 1964). Their distributional ranges are summarized in Table 1 . The southern boundary of T. longicornis coincides with the $20{ }^{\circ} \mathrm{C}$ isotherm in summer (Lindau, 2001), while C. hamatus persists as diapause eggs in the sediment to overwinter in the north and aestivate in the south during unfavourable temperature conditions in the water column (Marcus, 1989 and references therein). C. typicus seems relatively independent of temperature boundaries, since its distribution covers the Atlantic from the equatorial province to the subarctic province (van der Spoel and Heyman, 1983). T. stylifera occurs as far north as the $12.5{ }^{\circ} \mathrm{C}$ isotherm in winter (Lindau, 2001), but is occasionally advected to the English Channel by warm Atlantic currents from the south (A. John, personal communication). Morphologically, the congeners differ only slightly and their size ranges, assembled from different seasons and locations, largely overlap (Fig. 1).

In areas where these congener species coexist, like in the North Sea, their temporal distribution patterns differ considerably in the course of seasons. Whereas, C. hamatus occurs from April to September in coastal regions, C. typicus prefers the more saline and warmer waters of Atlantic origin and appears in the German Bight in the second half of the year (Fransz et al., 1991). Grant (1988) noticed a succession of Centropages congeners also in the Middle Atlantic Bight and assumed that it is based on the different temperature preferences of species. There, in a temperature range of $2-27^{\circ} \mathrm{C}, \mathrm{C}$. hamatus occurred only in the cold period below $17^{\circ} \mathrm{C}$, while $C$. typicus was always present. $\mathrm{He}$ concluded that $C$. hamatus is a cold water species, while $C$. typicus shows a wide tolerance for temperature. In the warmer Mediterranean, C. typicus is the only representative of the two Centropages species considered here. C. typicus dominates the copepod community in spring (Gilat et al., 1965; S. Nival, personal communication), but can be 
Table 1

Geographic distribution of C. typicus, C. hamatus, Temora longicornis and T. stylifera in the North Atlantic and adjacent seas

\begin{tabular}{|c|c|c|c|}
\hline Species & Characteristics & Geographic distribution & References \\
\hline \multirow[t]{6}{*}{ C. typicus } & \multirow{6}{*}{$\begin{array}{l}\text { southern- } \\
\text { intermediate } \\
\text { oceanic } \\
\text { epipelagic }\end{array}$} & warm Atlantic surface waters & Krause et al., 1995 \\
\hline & & Faroe-Shetland Channel & Jespersen, 1940 \\
\hline & & Mediterranean & Rose, 1933 \\
\hline & & Atlantic $6^{\circ} \mathrm{S}-62^{\circ} \mathrm{N}$ & Sars, 1928 \\
\hline & & Iceland and Faroes & Scott, 1911 \\
\hline & & Atlantic $36^{\circ}-62^{\circ} \mathrm{N}$ & Giesbrecht, 1892 \\
\hline \multirow[t]{9}{*}{ C. hamatus } & \multirow{9}{*}{$\begin{array}{l}\text { cold-temperate } \\
\text { neritic } \\
\text { diapause eggs }\end{array}$} & North Sea and Baltic & Krause et al., 1995 \\
\hline & & Sea to the fjords of Iceland & \\
\hline & & $\begin{array}{l}\text { western Spitsbergen, Barents } \\
\text { Sea, White Sea, Kara Sea }\end{array}$ & Klekowski and Weslawski, 1990 \\
\hline & & Newfoundland to Florida & Marcus, 1989 \\
\hline & & along the North American coast & (and references therein) \\
\hline & & Middle Atlantic Bight & Grant, 1988 \\
\hline & & White Sea & Pertzova, 1974 \\
\hline & & $41-66^{\circ} \mathrm{N}$ & Sars, 1928 \\
\hline & & $50-60^{\circ} \mathrm{N}$ & Giesbrecht, 1892 \\
\hline \multirow[t]{4}{*}{ T. longicornis } & \multirow{4}{*}{$\begin{array}{l}\text { cold-temperate } \\
\text { neritic } \\
\text { euryhaline } \\
\text { epipelagic }\end{array}$} & coasts from Portugal to northern Norway & Krause et al., 1995 \\
\hline & & western Spitsbergen, Barents Sea & Klekowski and Weslawski, 1990 \\
\hline & & $40-72^{\circ} \mathrm{N}$ & Sars, 1928 \\
\hline & & $50-60^{\circ} \mathrm{N}$ & Giesbrecht, 1892 \\
\hline \multirow[t]{5}{*}{ T. stylifera } & \multirow[t]{5}{*}{ warm-temperate } & occasionally English Channel & John, personal \\
\hline & & tropical Atlantic and Pacific, & communication \\
\hline & & Mediterranean, Red Sea & Mori, 1964 \\
\hline & & $\begin{array}{l}\text { Mediterranean, temperate } \\
\text { and warm Atlantic }\end{array}$ & Rose, 1957 \\
\hline & & Atlantic $37^{\circ} \mathrm{S}-46^{\circ} \mathrm{N}$ & Giesbrecht, 1892 \\
\hline
\end{tabular}

found reproducing almost during the whole year (Ianora and Buttino, 1990; HalsbandLenk et al., 2001).

The two Temora species hardly overlap in their geographical distribution range (Fig. 1). In the North Sea, T. longicornis is abundant at any time of the year and females are able to reproduce during the whole seasonal cycle (Halsband and Hirche, 2001). T. stylifera is a predominant copepod in the NW Mediterranean, which occurs in high numbers mainly during late summer and autumn (Gilat et al., 1965; S. Nival, personal communication), while females are potentially able to lay eggs throughout the year (Halsband-Lenk et al., 2001).

The geographical distribution and life cycles of these four species suggests that temperature is an important factor in their seasonal and regional abundance patterns. Temperature has traditionally been assumed to be a basic factor, ruling the physical environment (viscosity, etc.), limiting physiological processes (e.g. oxygen delivery within the organism) and biochemical reactions (e.g. enzyme activity), and finally determining growth and developmental rates (reviewed in Kinne, 1963). So far, it is hardly known which phase of the copepod life cycle is most sensitive to temperature limitation. Limitation might occur in the development of specific stages, e.g. nauplii (Pedersen and 
(a)
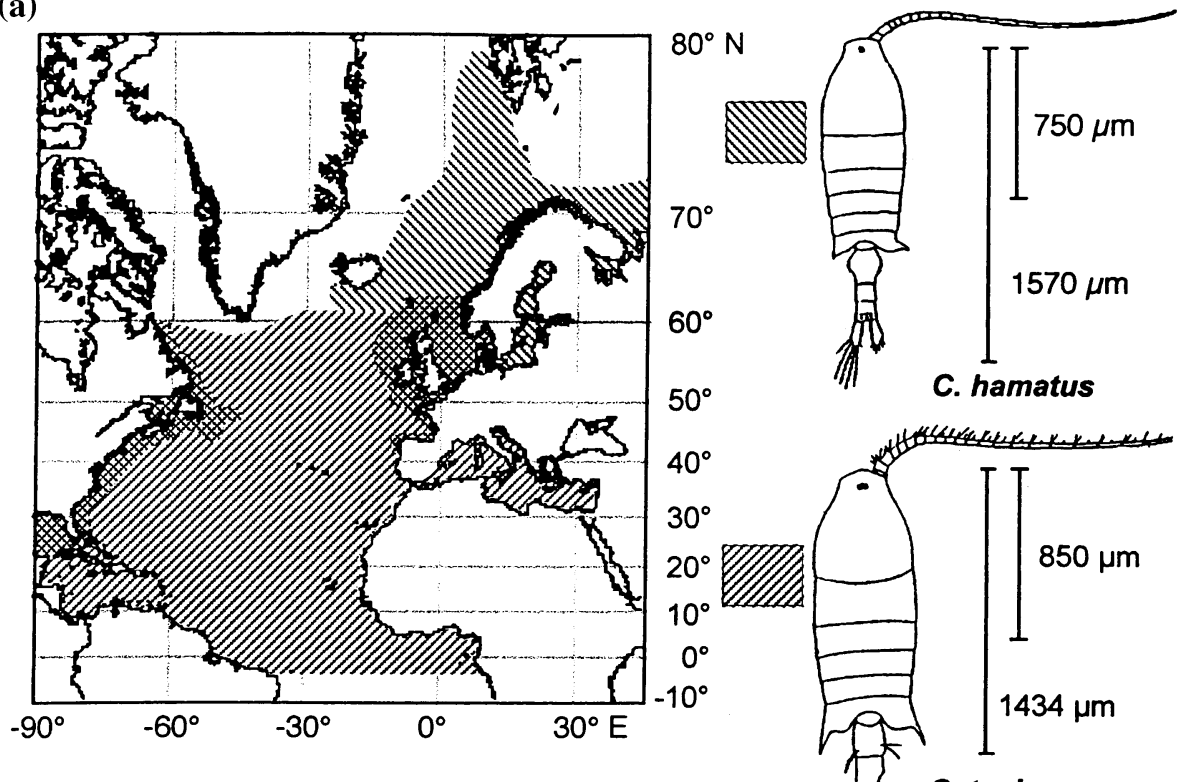

(b)
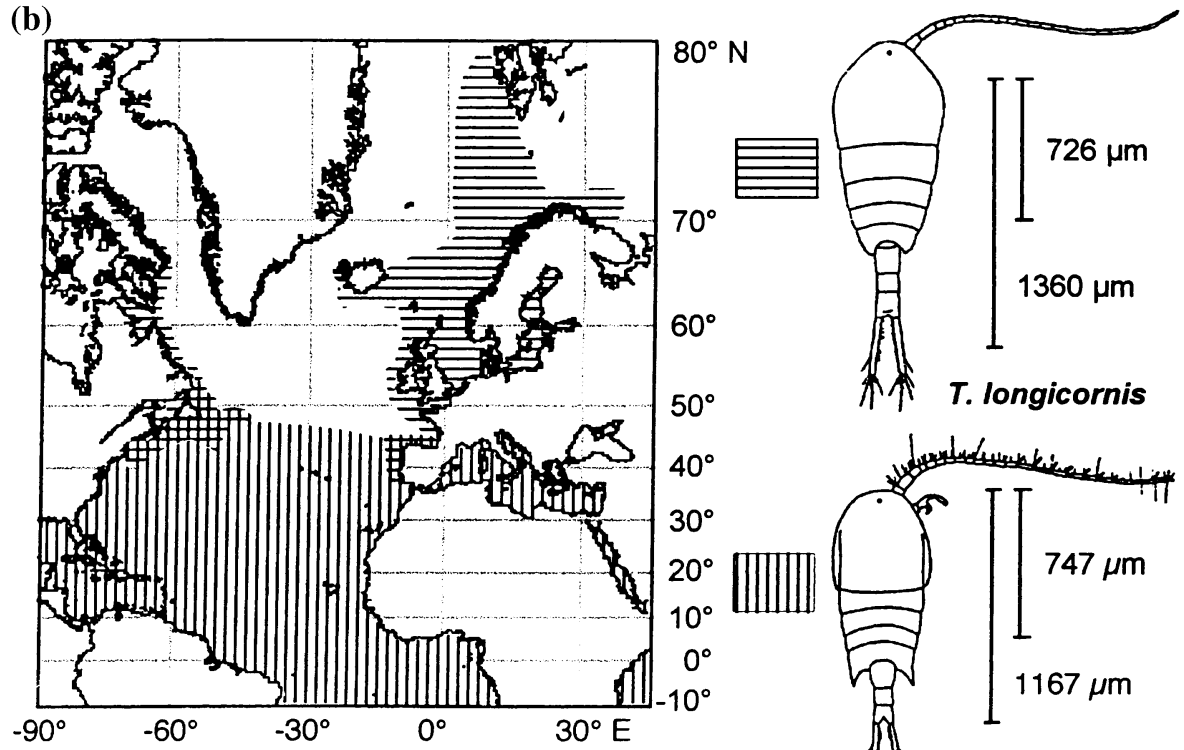

T. longicornis

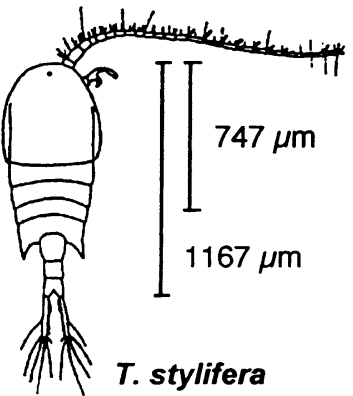

Fig. 1. Habit (after Rose, 1957; modified), range of prosome length in situ (Halsband-Lenk, partly unpublished) and geographical distribution in the Atlantic and adjacent seas of (a) C. typicus and C. hamatus, (b) T. longicornis and T. stylifera. 
Tande, 1992), or in reproductive biology. Earlier demographic studies concerned either egg development (Corkett, 1972; McLaren et al., 1969; McLaren, 1966), nauplii development (Corkett and McLaren, 1970) or generation time as a whole (McLaren, 1978), but rarely the different developmental stages. Most experimental studies were conducted in the natural temperature range of a species' habitat, without considering extreme temperatures (e.g. Abou-Debs and Nival, 1983).

Here, we tried to detect temperature limitation in all developmental stages and in reproductive biology. Laboratory experiments were conducted at Helgoland Island (SE North Sea) and in Villefranche-sur-Mer (NW Mediterranean) to compare the temperature responses of Centropages and Temora congeners in regard to different temperature regimes. Female thermal tolerance, egg production and development times were recorded in a temperature range from 2 to $35^{\circ} \mathrm{C}$. Rearing experiments were conducted in mesocosms at different temperatures to compare stage duration, generation time and mortality rates in congener populations.

\section{Material and methods}

\subsection{Sampling}

Plankton was collected at the sampling sites "Kabeltonne" $\left(54^{\circ} 11^{\prime} 3^{\prime \prime} \mathrm{N}, 7^{\circ} 54^{\prime} 0^{\prime \prime} \mathrm{E}\right)$ at Helgoland Roads in the south-eastern North Sea with a Calcofi net ( $280 \mu \mathrm{m}$ mesh size $)$ and "Point B" $\left(43^{\circ} 41^{\prime} 10^{\prime \prime} \mathrm{N}, 7^{\circ} 19^{\prime} 00^{\prime \prime} \mathrm{E}\right)$ at the entrance of the Bay of Villefranche-sur-Mer in the north-western Mediterranean using a net of the type "Superhomogène" $(280 \mu \mathrm{m}$ mesh size). These stations are of a similar longitude position, but represent two different climatic regions due to the different latitudes: the boreal North Sea with an annual surface temperature range from 0 to $20{ }^{\circ} \mathrm{C}$, and the warm-temperate Mediterranean Sea, where surface temperatures vary between 13 and $26{ }^{\circ} \mathrm{C}$ (Fig. 2).

Specimens of C. typicus, C. hamatus and T. longicornis from Helgoland Roads (indexed ${ }_{\text {NS }}$ further on) were collected in summer 1999, when surface temperature ranged

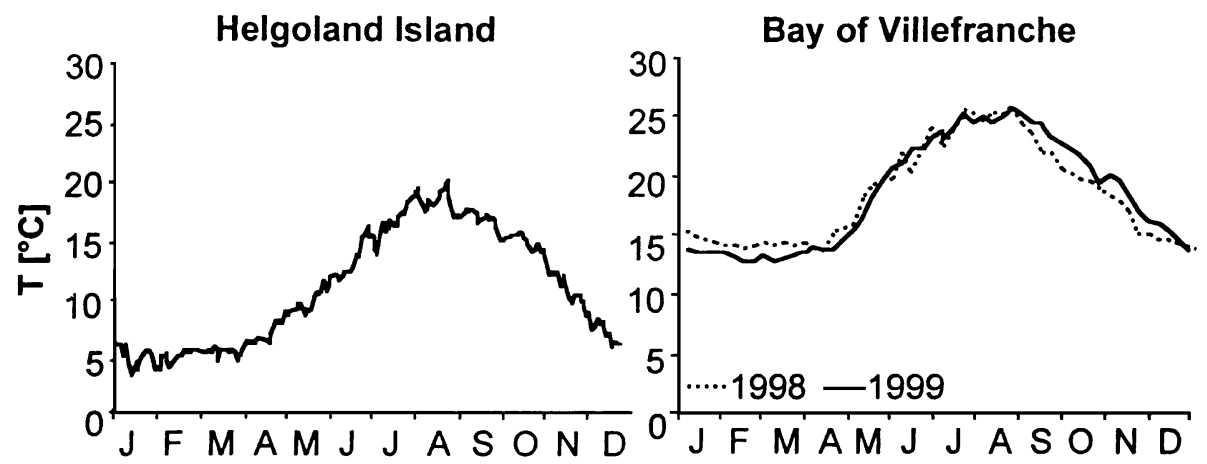

Fig. 2. Seasonal cycle of surface temperature in the North Sea (Helgoland Roads) in 1999 and in the Mediterranean (Bay of Villefranche) in 1998 and 1999. 
between 14 and $19{ }^{\circ} \mathrm{C}$. Experiments with C. typicus and T. stylifera in the Mediterranean (indexed ${ }_{\mathrm{Med}}$ ) were carried out in autumn 1998 at surface temperatures around $17^{\circ} \mathrm{C}$. They

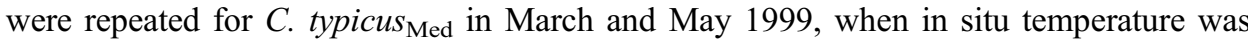
around $15{ }^{\circ} \mathrm{C}$. The plankton was brought to the laboratory within $1 \mathrm{~h}$ and adult females were sorted for incubation. Experiments were conducted in temperature-controlled cold rooms at 15 and $20{ }^{\circ} \mathrm{C}\left( \pm 0.5^{\circ} \mathrm{C}\right)$, all other incubations were carried out in water bathes $\left(T \pm 0.2{ }^{\circ} \mathrm{C}\right)$. The light cycle was $12 \mathrm{~h}$ dimmed light/12 $\mathrm{h}$ darkness.

\subsection{Survival of adult females and egg production}

Survival of adult females and egg production rates were measured during periods of high reproductive activity in the field (autumn 1998 in Villefranche, summer 1999 at Helgoland Island). In order to analyse seasonal variations, experiments were repeated in spring with $C$. typicus in the Mediterranean. About 12-45 females were kept individually in small glasses of approximately $15 \mathrm{ml}$ for 5 days. Before incubations started, the animals were adapted to the experimental temperature during $24 \mathrm{~h}$ by cooling (or warming) in steps of $5^{\circ} \mathrm{C}$ in water baths. Filtered seawater $(0.45 \mu \mathrm{m})$ enriched with 15,000 cells ml${ }^{-1}\left(\approx 4 \mu \mathrm{g} \mathrm{C} \mathrm{ml}^{-1}\right)$ of the flagellate Hymenomonas elongata was offered as food. The dishes were checked for dead animals, eggs and faecal pellets twice a day, and eggs and pellets were removed. Egg cannibalism was accounted for by including empty egg shells in the counts. Individuals that died before the end of the experiment or laid no eggs were discarded. Viable individuals were preserved in $4 \%$ buffered formalin for later measurements of prosome length.

Females from the North Sea were incubated at 2, 5, 7.5 (except $C$. hamatus), 10, 12.5 (except $C$. typicus), 15, 20, 22.5 (except $C$. hamatus), 25, 30 and $35{ }^{\circ} \mathrm{C}$. Experimental temperatures for specimens from the Mediterranean were 2, 5, 7.5, 8, 10, 15, 20, 22.5 (except T. stylifera), 25, 30 and $35^{\circ} \mathrm{C}$. Additional data were available for T. longicornis, incubated at $0{ }^{\circ} \mathrm{C}$ in March 1996 with Dunalliella tertiolecta as food.

Egg production was expressed as mean egg production rate of all egg-laying females during 5 days (eggs female ${ }^{-1}$ day $^{-1}$ ) and as cumulative egg production over 5 days of incubation (eggs female ${ }^{-1}$ ). Since all females of $T$. stylifera died at $20{ }^{\circ} \mathrm{C}$ within the incubation time of 5 days, egg production in this case was calculated for all females that survived until day 4.5 .

Mean female carbon was measured by the high-temperature combustion method (Salonen, 1979; Tanskanen, 1994) from individuals sampled between September 1995 and June 1996, and in summer 1999 (North Sea), and in autumn 1998 and spring 1999 (Mediterranean, see Halsband-Lenk et al., 2001). Mean egg carbon was estimated from

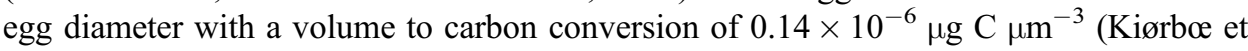
al., 1985). Mean female carbon and mean egg carbon were used to calculate a weight specific egg production rate (SEPR).

\subsection{Prosome length}

Prosome length of preserved females from the incubations was measured with a digitizing video system (Scion Image 1.6 ${ }^{\circledR}$ ). Differences in size between experiments were tested with ANOVA and Scheffe's post hoc tests. 


\subsection{Embryonic development}

Eggs were obtained from freshly captured females incubated $24 \mathrm{~h}$ in filtered seawater at $15{ }^{\circ} \mathrm{C}$. Embryonic development times were determined from 2 to $30{ }^{\circ} \mathrm{C}$ in summer 1999 for all North Sea species. Complementary results for eggs of T. longicornis, incubated from 0 to $16{ }^{\circ} \mathrm{C}$ in March and June 1996 were included. Development times in the Mediterranean were recorded from 2 to $30^{\circ} \mathrm{C}$ in June 1998, March and May 1999 for $C$. typicus and in November 1998 for both C. typicus and T. stylifera. Hatching was controlled three times a day until the first nauplii appeared. Then nauplii were counted every $1-2 \mathrm{~h}$ (except overnight) until all eggs had hatched or no more development occurred. Development times are defined as the time needed by $50 \%$ of all viable nauplii to hatch (median development times).

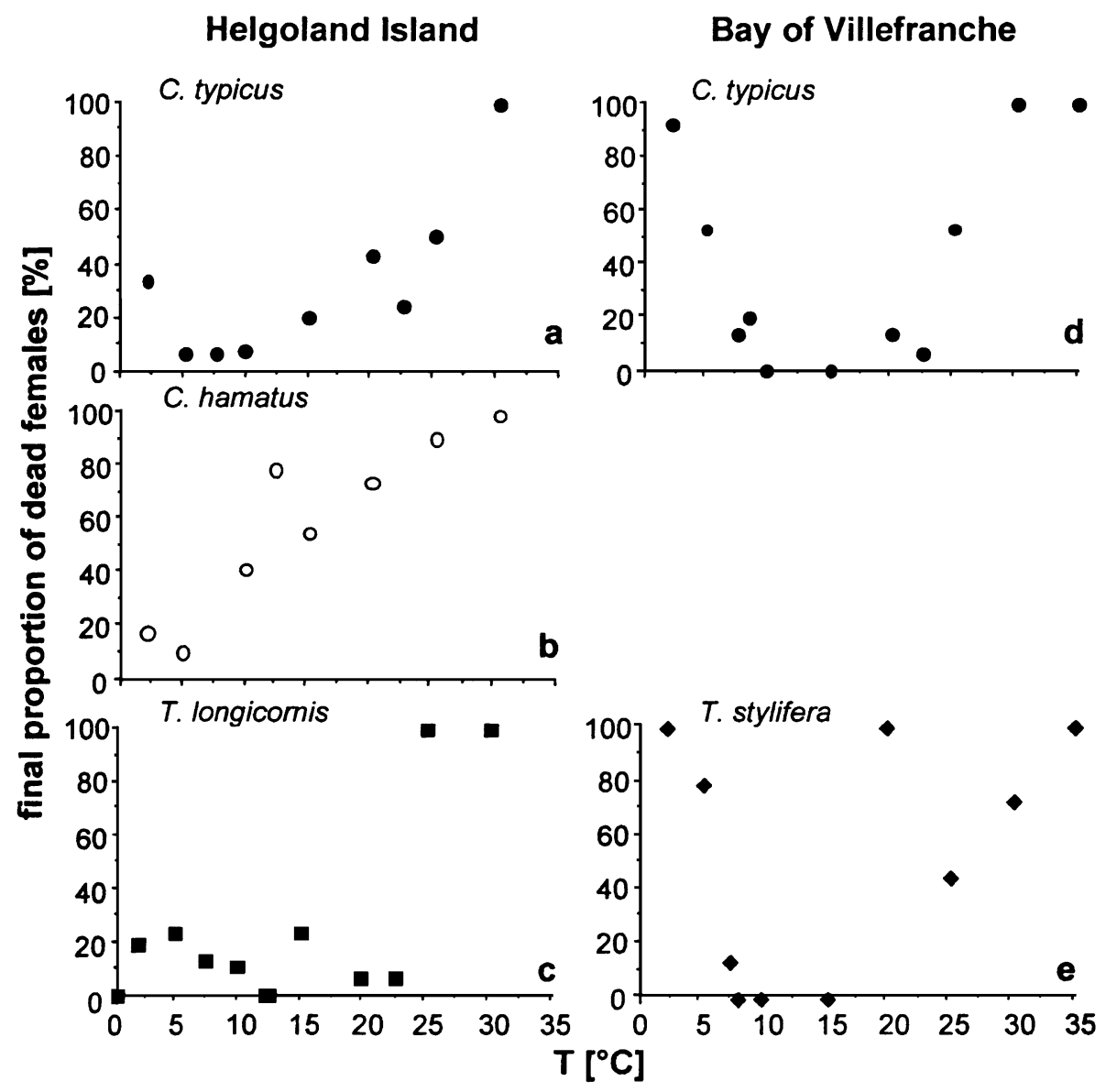

Fig. 3. Total mortality of adult females after 5 days of incubation at different temperatures. 
The temperature response of embryonic development is described by Bělehrádek's function of the form $D=a(T-\alpha)^{b}$, with $b$ assumed as constant $(-2.05)$ for all species (McLaren et al., 1969). Differences between seasons were compared by ANCOVA analysis, after ln-transformation of development times.

\subsection{Post-embryonic development}

In the North Sea, cohorts of all three species were raised at 15 and $20{ }^{\circ} \mathrm{C}$ and C. typicus additionally at $10^{\circ} \mathrm{C}$ in summer 1999 . In the Mediterranean, C. typicus was cultured at 12 , 15 and $18{ }^{\circ} \mathrm{C}$ in spring 1998 , T. stylifera at 10,15 and $20^{\circ} \mathrm{C}$ in autumn 1998 . For initiation of cultures, around 200 freshly captured females and 50 males were kept in Plexiglas cylinders, closed at the bottom with gauze of $280 \mu \mathrm{m}$, and immersed in a 5-1 beaker filled with filtered seawater $(0.45 \mu \mathrm{m})$. To induce high spawning rates, the culture was enriched with 15,000 cells $\mathrm{ml}^{-1}$ of $H$. elongata and the beaker softly oxygenated with air. Spawned eggs fell through the mesh and were collected at the bottom of the beaker. After a spawning period of $24-48 \mathrm{~h}$, the adults were removed and sampling started.

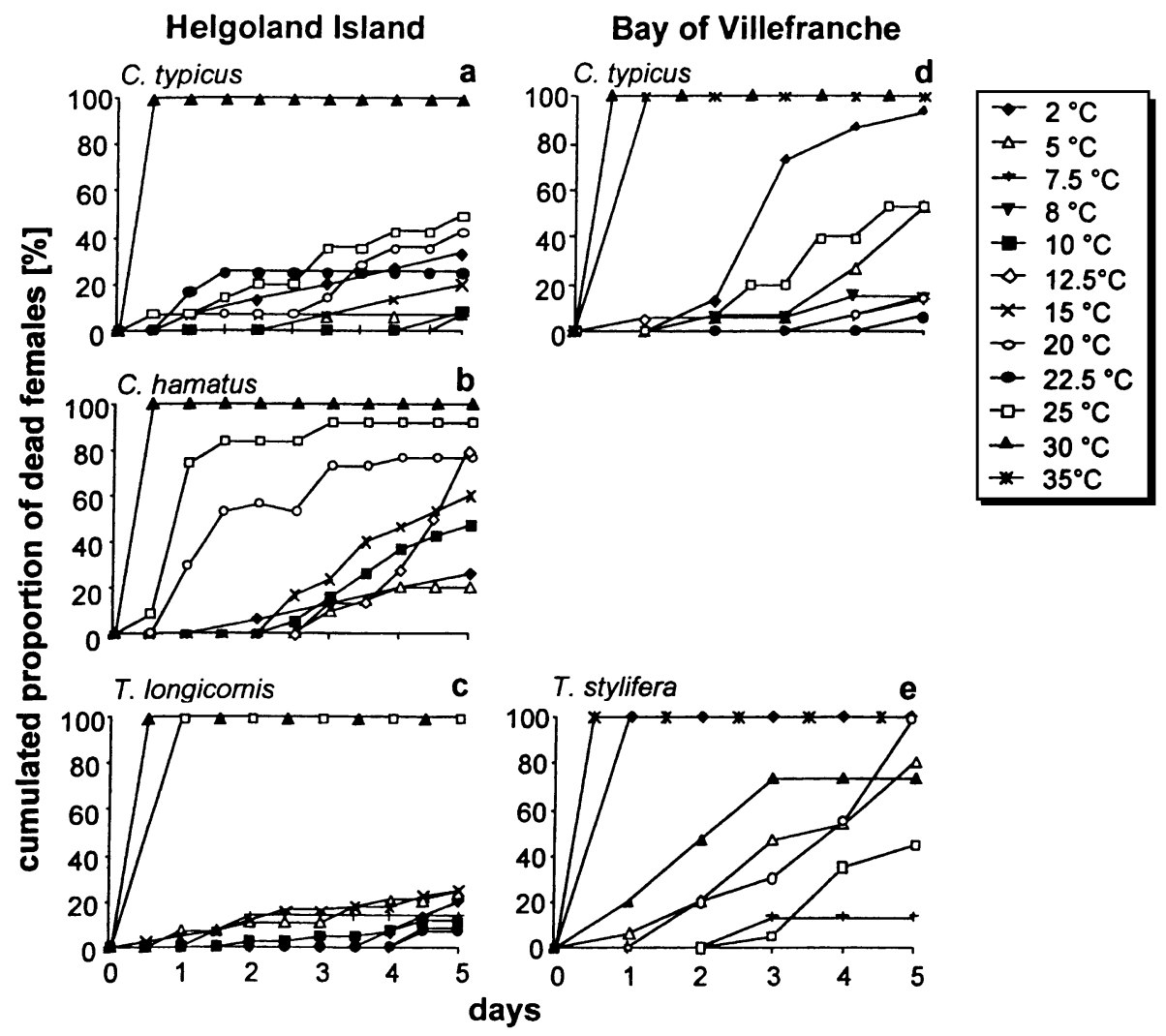

Fig. 4. Cumulative proportions of dead females incubated 5 days at different temperatures. 
Since the size spectra of ingested particles changes within the development of the copepods, around 100,000 cells $\mathrm{ml}^{-1}$ of Isochrysis galbana were added after removal of the adults. The size of these algae $(4-7 \mu \mathrm{m})$ corresponds best to the food size spectra of the youngest nauplii stages (Nival and Nival, 1976). When the first N3 appeared, $I$. galbana progressively was exchanged by $H$. elongata $(15 \mu \mathrm{m})$ to $\approx 10,000$ cells $\mathrm{ml}^{-1}$ $\left(\approx 2.6 \mu \mathrm{g} \mathrm{C} \mathrm{ml}^{-1}\right)$. Every day a subsample of $1-4 \%$ was taken to estimate the abundance of the larval stages and control food concentration.

Development time was defined as the time when $50 \%$ of the population had completed molting to a given stage, calculated with the help of least square regressions. Stage duration then was calculated as the interval between the development time to a given stage and the time to the subsequent stage (Landry, 1983). Females and males were not distinguished, since they appeared simultaneously. Mortality rates were estimated from the slope of linear regressions of logarithmic transformed population abundances, after correction of population size for mortality due to sampling (Aksnes et al., 1997). Two

Helgoland Island

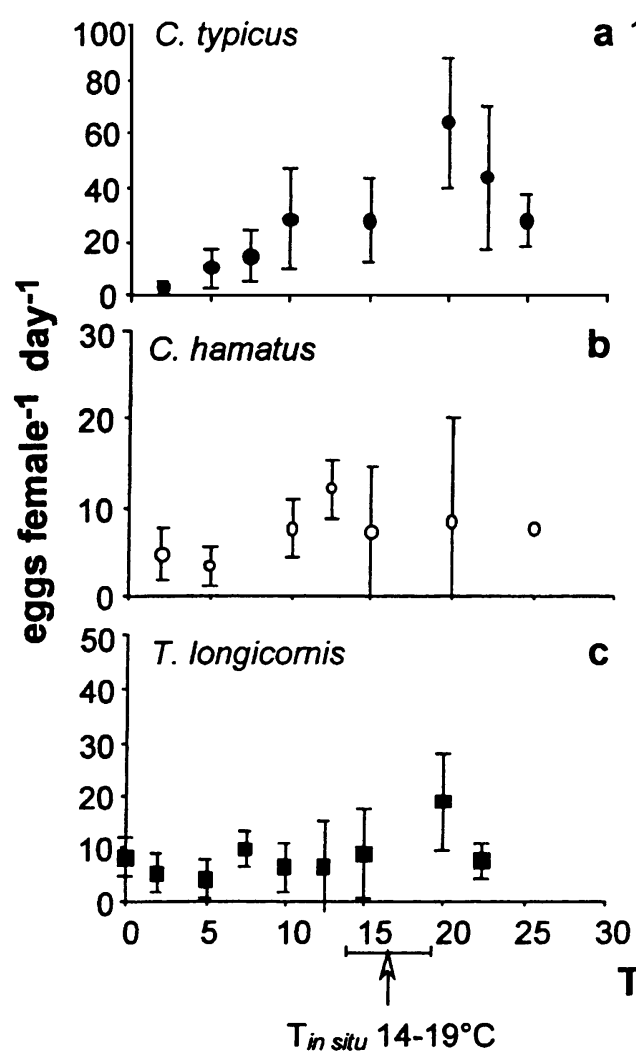

Bay of Villefranche

a 100 C. typicus

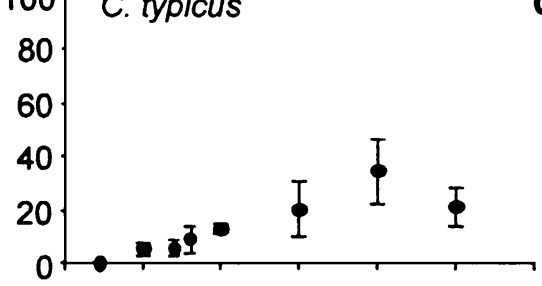

d

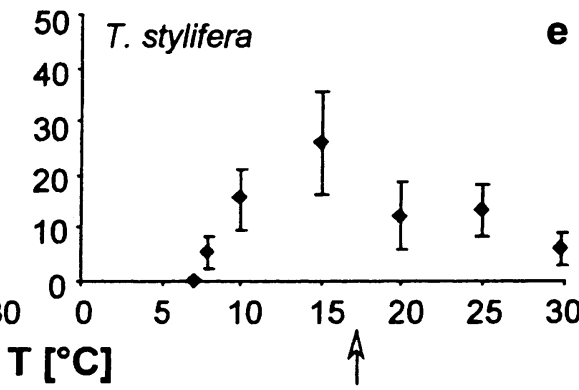

Tin situ $17^{\circ} \mathrm{C}$

Fig. 5. Temperature impact on egg production rates. Vertical bars indicate standard deviation. 
regressions per population were calculated, one from egg to $\mathrm{CI}$, the other from $\mathrm{CI}$ to $50 \%$ adulthood. In some experiments, the cohorts suddenly broke down for unknown reasons so that populations did not reach adulthood (Table 3 ). In those cases, stage duration was estimated only for all instars available.

\section{Results}

\subsection{Thermal impact on survival, reproduction and development}

\subsubsection{Female thermal tolerance (FTT)}

FTT followed an optimum curve in C. typicus ${ }_{\mathrm{NS}}+$ Med and T. stylifera with increased mortality at temperatures higher and lower than the optimum (Fig. 3). Mortality of $C$. hamatus increased linearly with temperature $\left(12.5^{\circ} \mathrm{C}\right.$ excluded $)$, while no clear pattern was found in T. longicornis.

The cumulated numbers of dead females during the 5 days of observations are presented in Fig. 4 for the four species and for the different temperatures of incubation. In general, two patterns were observed: (1) hyperbolic curves with a very high mortality of

\section{Helgoland Island}
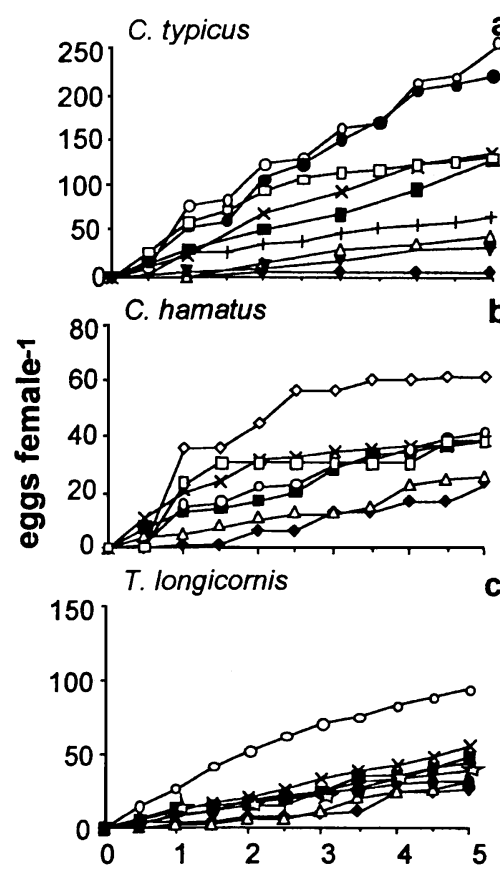

\section{Bay of Villefranche}

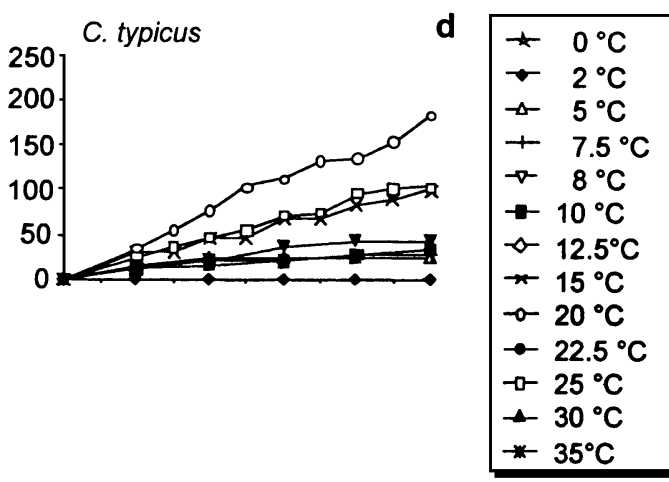

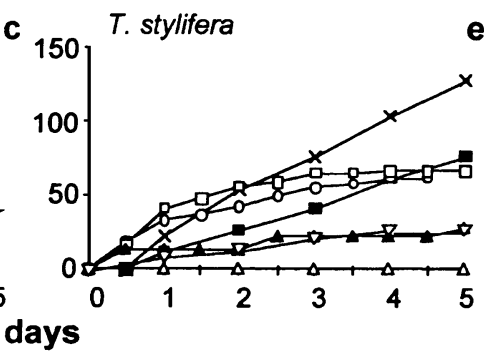

Fig. 6. Cumulative egg production during 5 days at different temperatures. 
females during the first days followed by a constant proportion of survivors, (2) a constant death rate, or (3) the proportion of dead females increasing with age. For all species, pattern (1) was recorded at the highest temperatures, i.e. 25 and $30{ }^{\circ} \mathrm{C}$ for $T$. longicornis, $30{ }^{\circ} \mathrm{C}$ for C. typicus $_{\mathrm{NS}}$ and C. hamatus, 30 and $35^{\circ} \mathrm{C}$ for C. typicus Med $_{\text {and } T \text {. stylifera. }}$. The same type of response was observed in C. typicus $\mathrm{NS}_{\mathrm{NS}}$ at $22.5^{\circ} \mathrm{C}$ and in $C$. hamatus at $25{ }^{\circ} \mathrm{C}$, and to a less degree, at $20{ }^{\circ} \mathrm{C}$. Pattern (2) was observed at all other temperatures in C. typicus ${ }_{\mathrm{NS}}$ and T. longicornis. Mortality of T. stylifera reached $100 \%$ at $20{ }^{\circ} \mathrm{C}$ due to constant death rate. Pattern (3) occurred in C. typicus Med $_{\text {al }}$ at all temperatures from 2 to 25 ${ }^{\circ} \mathrm{C}$, in C. hamatus at $12.5^{\circ} \mathrm{C}$ and in T. stylifera at $25^{\circ} \mathrm{C}$.

\subsubsection{Reproductive thermal response (RTR)}

RTR generally showed an optimum curve (Fig. 5). Optimal temperature was around 20 ${ }^{\circ} \mathrm{C}$ for C. typicus $\mathrm{NS}_{\mathrm{N}}$ Med and for T. longicornis, whereas $C$. hamatus spawned most eggs at $12.5^{\circ} \mathrm{C}$ and $T$. stylifera at $15^{\circ} \mathrm{C}$. Egg production rate over 5 days mostly was constant (Fig. 6), other in cases reproduction stopped after a few days $\left(C\right.$. typicus $s_{\mathrm{NS}}$ at $25^{\circ} \mathrm{C}, C$. hamatus at $12.5,15$ and $25{ }^{\circ} \mathrm{C}$, T. stylifera at 25 and $30^{\circ} \mathrm{C}$ ). Weight specific production

Helgoland Island
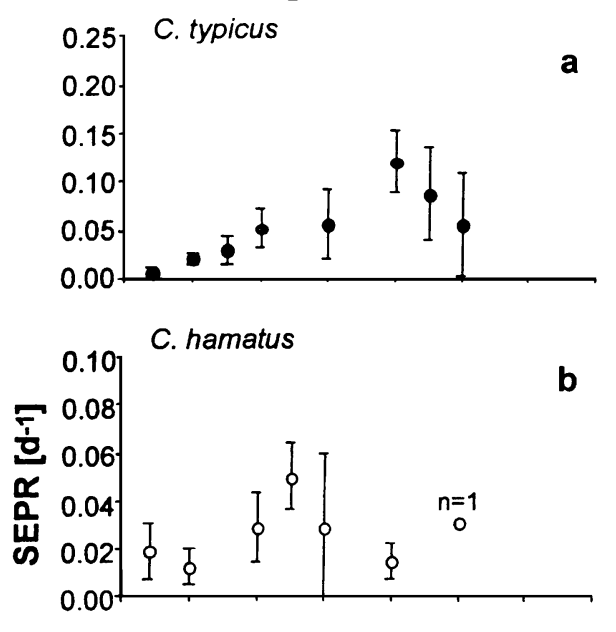

b

\section{Bay of Villefranche}

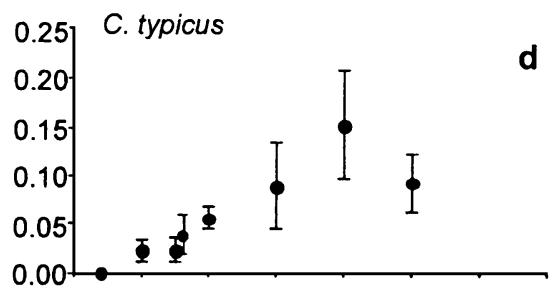

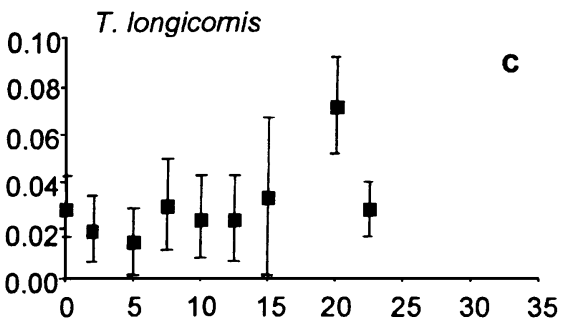

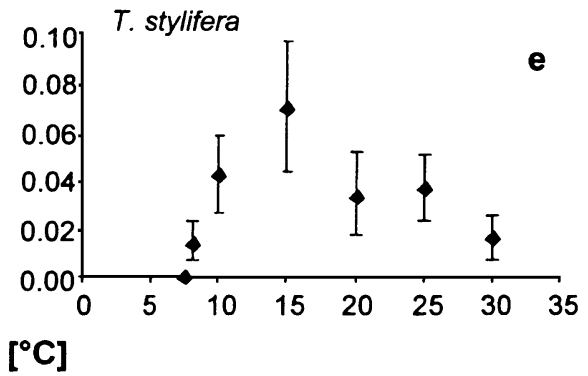

Fig. 7. Temperature impact on weight specific egg production. Vertical bars indicate standard deviation. 
rates (SEPR) were in the same range for all species except $C$. typicus and varied between $6 \%$ and $7.5 \%$ day $^{-1}$ at the optimal temperatures (Fig. $7 \mathrm{~b}, \mathrm{c}, \mathrm{e}$ ). Both C. typicus populations had higher specific production reaching $11 \%$ NS and $16 \%$ Med at the optimum, respectively (Fig. 7a,d).

\subsubsection{Prosome length of females}

Prosome length of females used in our experiments showed little variability within species (Fig. 8) in comparison to the range of prosome length compiled from different

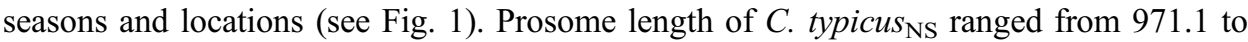
$1415.9 \mu \mathrm{m}$ with a mean of $1158.9 \pm 83.6 \mu \mathrm{m}$. Specimens of $C$. typicus $s_{\text {Med }}$ were smaller, ranging from 921.8 to $1174.0 \mu \mathrm{m}$ with a mean of $1036.7 \pm 61.5 \mu \mathrm{m}$. Body size of $C$. hamatus was between 793.1 and $1146.8 \mu \mathrm{m}$, with a mean of $944.6 \pm 79.5 \mu \mathrm{m}$. $T$. longicornis and T. stylifera females had a similar mean prosome length of $951.1 \pm 71.3$ and $965.7 \pm 47.9 \mu \mathrm{m}$, respectively. The size range of $T$. longicornis from 774.3 to 1212.6 $\mu \mathrm{m}$ (mean $951.1 \pm 71.3 \mu \mathrm{m}$ ) was broader than that of $T$. stylifera with $876.8-1073.7 \mu \mathrm{m}$ (mean $965.7 \pm 47.9 \mu \mathrm{m}$ ). Size differences between experiments were not significant in a

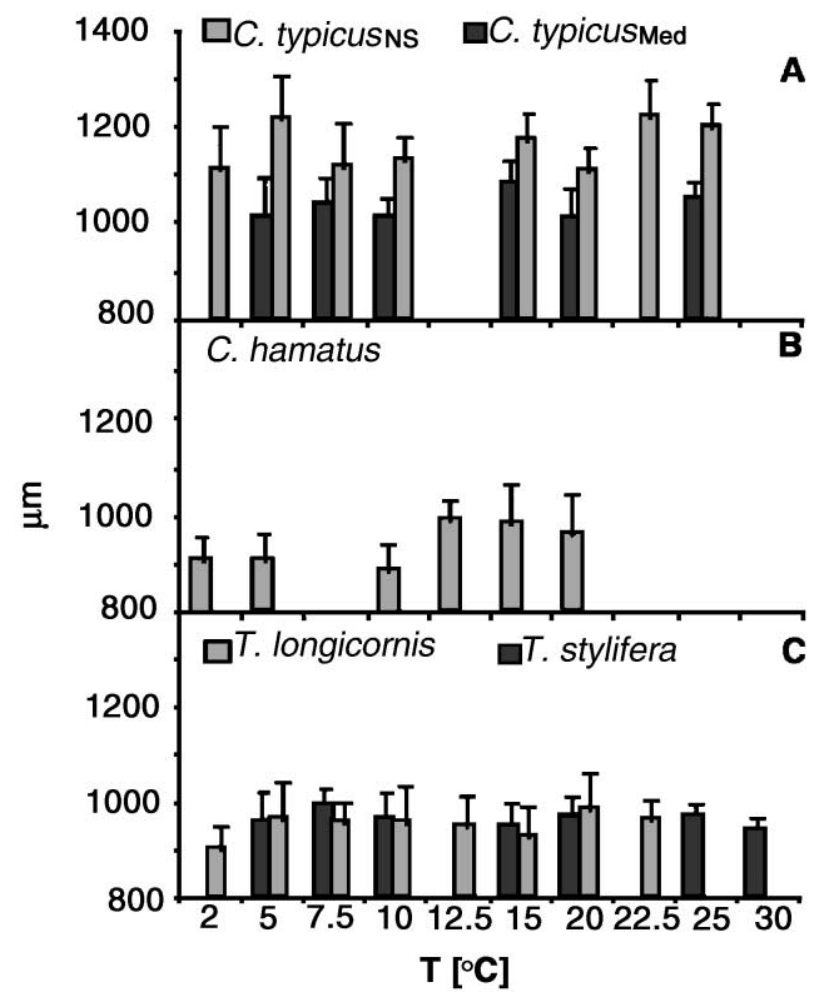

Fig. 8. Prosome length of females incubated in experiments. Vertical bars indicate standard deviation. 
given population, except in $C$. typicus $s_{\mathrm{Med}}$ and $C$. hamatus. In both cases, females were greater at $15{ }^{\circ} \mathrm{C}$ than at $10{ }^{\circ} \mathrm{C}(p<0.0001)$.

\subsubsection{Embryonic thermal response (ETR) and hatching success}

Temperature impact on embryonic duration is presented in Fig. 9. At all temperatures where eggs were produced hatching was also possible, except in T. stylifera at $30{ }^{\circ} \mathrm{C}$ and C. typicus $s_{\text {Med }}$ at $2{ }^{\circ} \mathrm{C}$. Embryonic development times decreased with increasing temperature following Bělehrádek functions in all species (Table 2). In few cases (Fig. 9b,d), embryonic duration increased at higher temperatures, as at $25^{\circ} \mathrm{C}$ in C. hamatus and at 28 ${ }^{\circ} \mathrm{C}$ in $\mathrm{C}$. typicus $\mathrm{Med}_{\mathrm{Med}}$. Hatching success was maximum or very high at any temperature

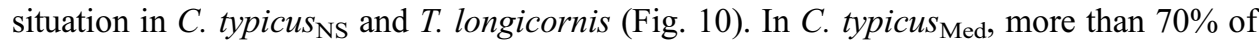
nauplii hatched at all temperatures. A more variable proportion of viable nauplii was observed in $C$. hamatus ranging from $34 \%$ to $89 \%$. In $T$. stylifera, survival of eggs increased linearly with temperature from $52 \%$ at $10{ }^{\circ} \mathrm{C}$ to $90 \%$ at 20 and $25{ }^{\circ} \mathrm{C}$.

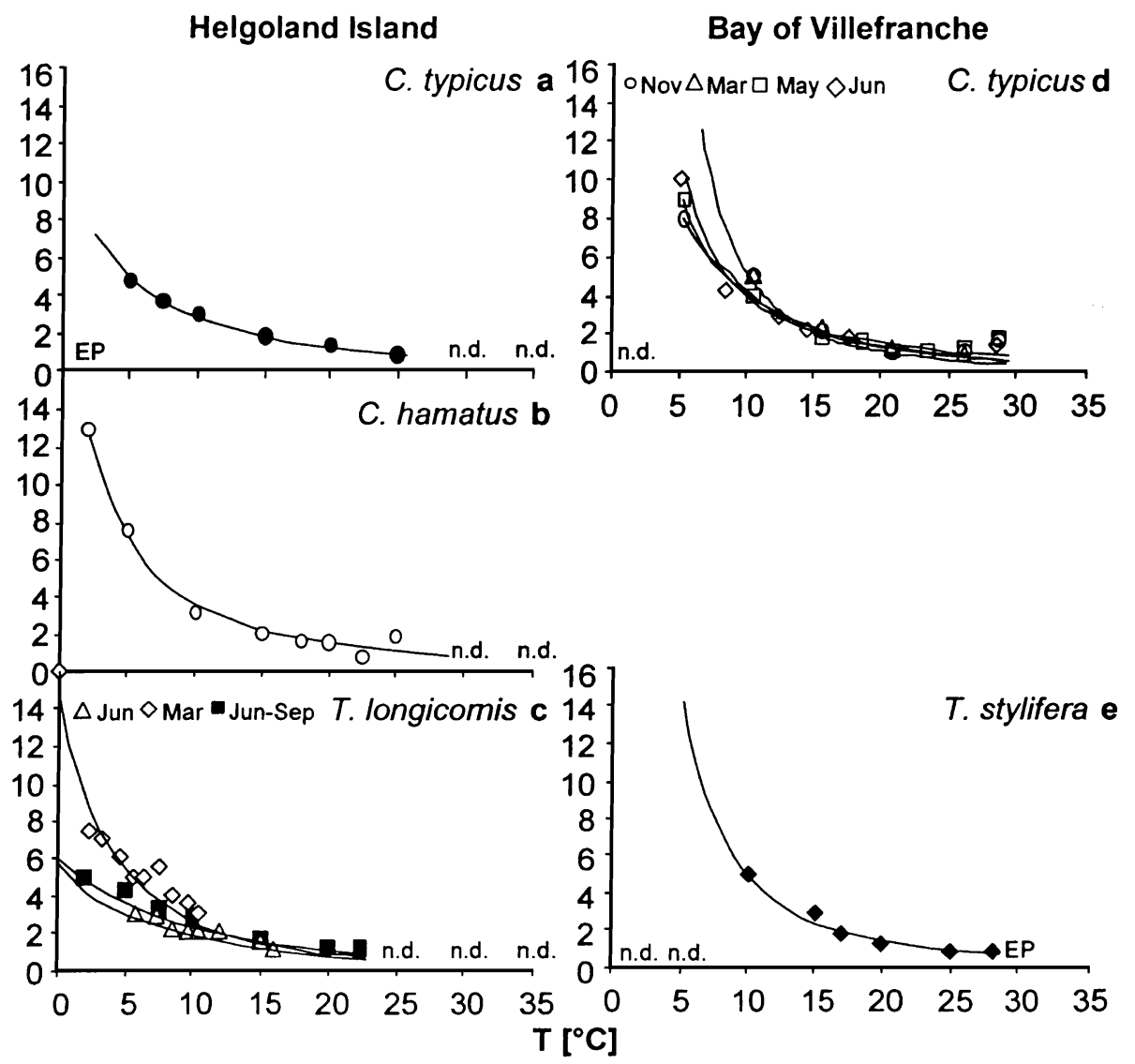

Fig. 9. Embryonic development times fitted with Belehrádek curves. n.d. = no development, EP=egg production observed. 
Table 2

Belehrádek functions of embryonic development at different temperatures

\begin{tabular}{llll}
\hline & Species & Equation & References \\
\hline Northern Atlantic/North Sea & C. typicus & & \\
& Jul-Sep & $D=1535.3(T+11.6)^{-2.05}$ & this study \\
& & $D=1068(T+9.37)^{-2.05}$ & McLaren et al., 1989 \\
C. hamatus & & \\
Jul-Sep & $D=1148.9(T+6.9)^{-2.05}$ & this study \\
T. longicornis & & \\
Jul-Sep & $D=2469.5(T+18.2)^{-2.05}$ & this study \\
Mar & $D=1121.7(T+8.1)^{-2.05}$ & this study \\
& Jun & $D=1474.9(T+14.7)^{-2.05}$ & this study \\
& & $D=1346.0(T+10.4)^{-2.05}$ & Corkett and McLaren, 1970 \\
& C. typicus & & \\
Nov & $D=1579.0(T+8.0)^{-2.05}$ & this study \\
Mar & $D=586.7(T+0.3)^{-2.05}$ & this study \\
& May & $D=1059.5(T+5.3)^{-2.05}$ & this study \\
& Jun & $D=1113.3(T+5.0)^{-2.05}$ & this study \\
& T. stylifera & & \\
Nov & $D=791.0(T+1.8)^{-2.05}$ & this study \\
Autumn & $D=3.5(T-12.0)^{-0.50}$ & Abou-Debs and Nival, 1983 \\
& Spring & $D=45.4(T+0.5)^{-1.14}$ & Abou-Debs and Nival, 1983 \\
\hline
\end{tabular}

\subsubsection{Post-embryonic development and mortality rates}

The proportions of the population having completed a given moult versus time during cultivation at different temperatures and resulting linear regressions are presented in Figs. 11-13. Stage durations and mortality rates are summarized in Table 3. Naupliar and copepodite development, as well as generation times, are compared in Table 4.

For better comparison, stage durations are presented graphically on Fig. 14. Egg duration was higher than or equal to naupliar stages in all Centropages populations; late copepodites showed the slowest development (Fig. 14a-e). In the Temora species, naupliar durations were similar to copepodite durations, except when mortality stopped development (Fig. 14f-h).

\subsection{Comparison of the two C. typicus populations and the congener pairs}

\subsubsection{C. typicus in the North Sea and the Mediterranean}

FTT differed between the two $C$. typicus populations in the North Sea and the Mediterranean (Table 5). While mortality rates of females were similar at upper temperatures, they were higher in the Mediterranean at the lower temperature range. Optimal survival occurred at $5-10^{\circ} \mathrm{C}$ in the North Sea, but at $10-15^{\circ} \mathrm{C}$ in the Mediterranean (Fig. $4 \mathrm{a}, \mathrm{d})$.

In contrast to FTT, RTR was very similar in the two populations, except at $2{ }^{\circ} \mathrm{C}$, where C. typicus $_{\mathrm{NS}}$ produced eggs, whereas C. typicus $_{\mathrm{Med}}$ did not (Fig. 6a,d). At the optimum (20 ${ }^{\circ} \mathrm{C}$ ), the larger C. typicus $_{\mathrm{NS}}$ females produced more eggs (54.5 eggs female ${ }^{-1}$ day $^{-1}$ ) than the smaller C. typicus Med $_{\text {(34. }}$ eggs female ${ }^{-1}$ day $\left.^{-1}\right)$. On a weight-specific base, 


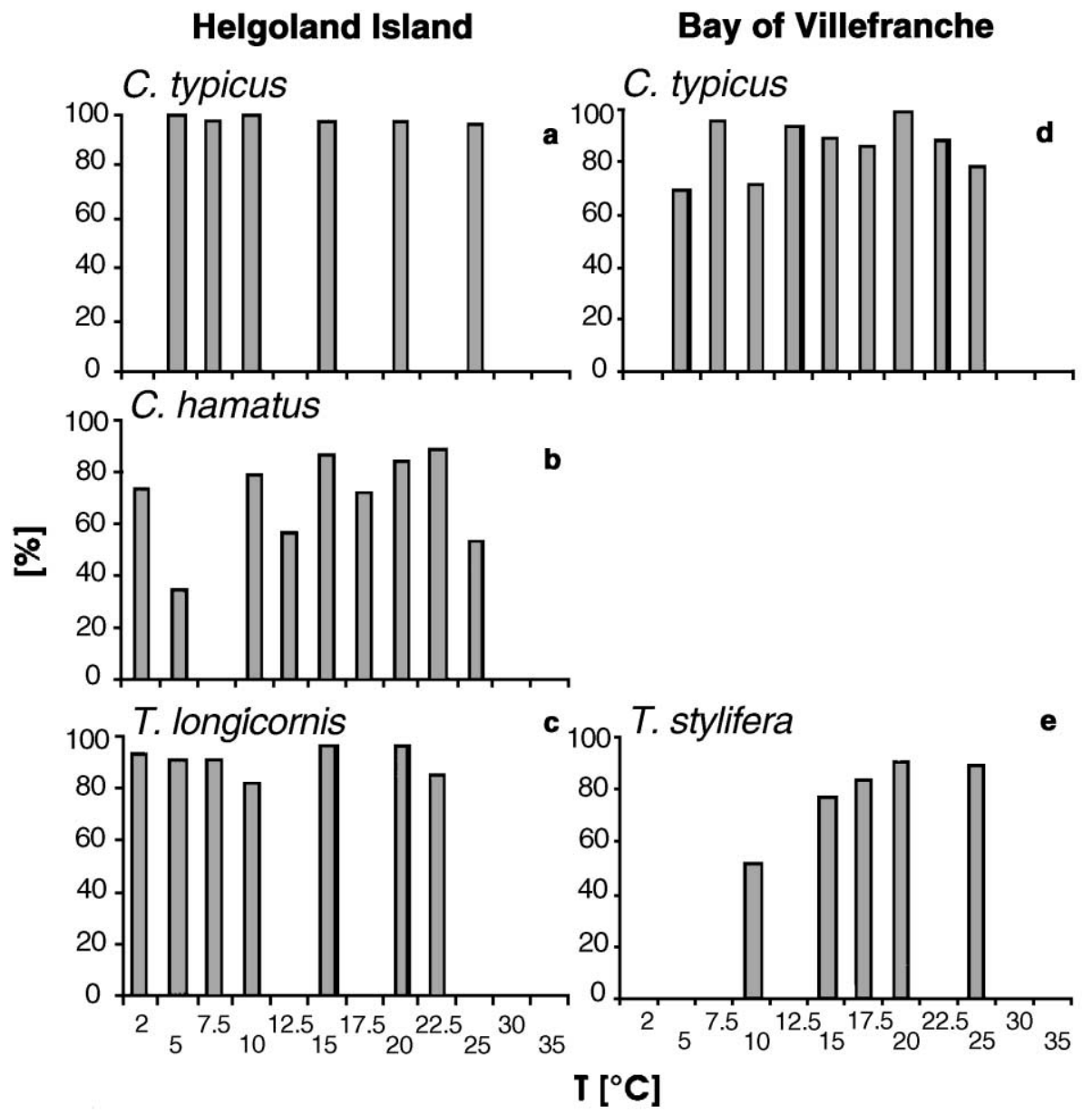

Fig. 10. Hatching success of eggs incubated at different temperatures.

egg production was similar in both populations with a slightly higher maximum of $C$. typicus $_{\text {Med }}$ (Fig. 7a,d).

Complementary experiments with C. typicus $_{\text {Med }}$ (Fig. 15) showed very similar RTR in November, March and May, indicating independence from season. Optimum temperature of egg production remained invariable at $20{ }^{\circ} \mathrm{C}$, only the magnitude of egg production varied seasonally, while body size was almost constant. Likely, the seasonal variability of ETR was not significant (Fig. 9d).

The lower temperature limit of embryonic development was $5{ }^{\circ} \mathrm{C}$ in both populations, although females were able to produce eggs at $2{ }^{\circ} \mathrm{C}$ in the North Sea. At the upper temperature range, embryonic duration was shortest at $25{ }^{\circ} \mathrm{C}$ at both stations. At $28{ }^{\circ} \mathrm{C}$, hatching was retarded in Mediterranean eggs; no data were available for the North Sea (Fig. 9a,d). 

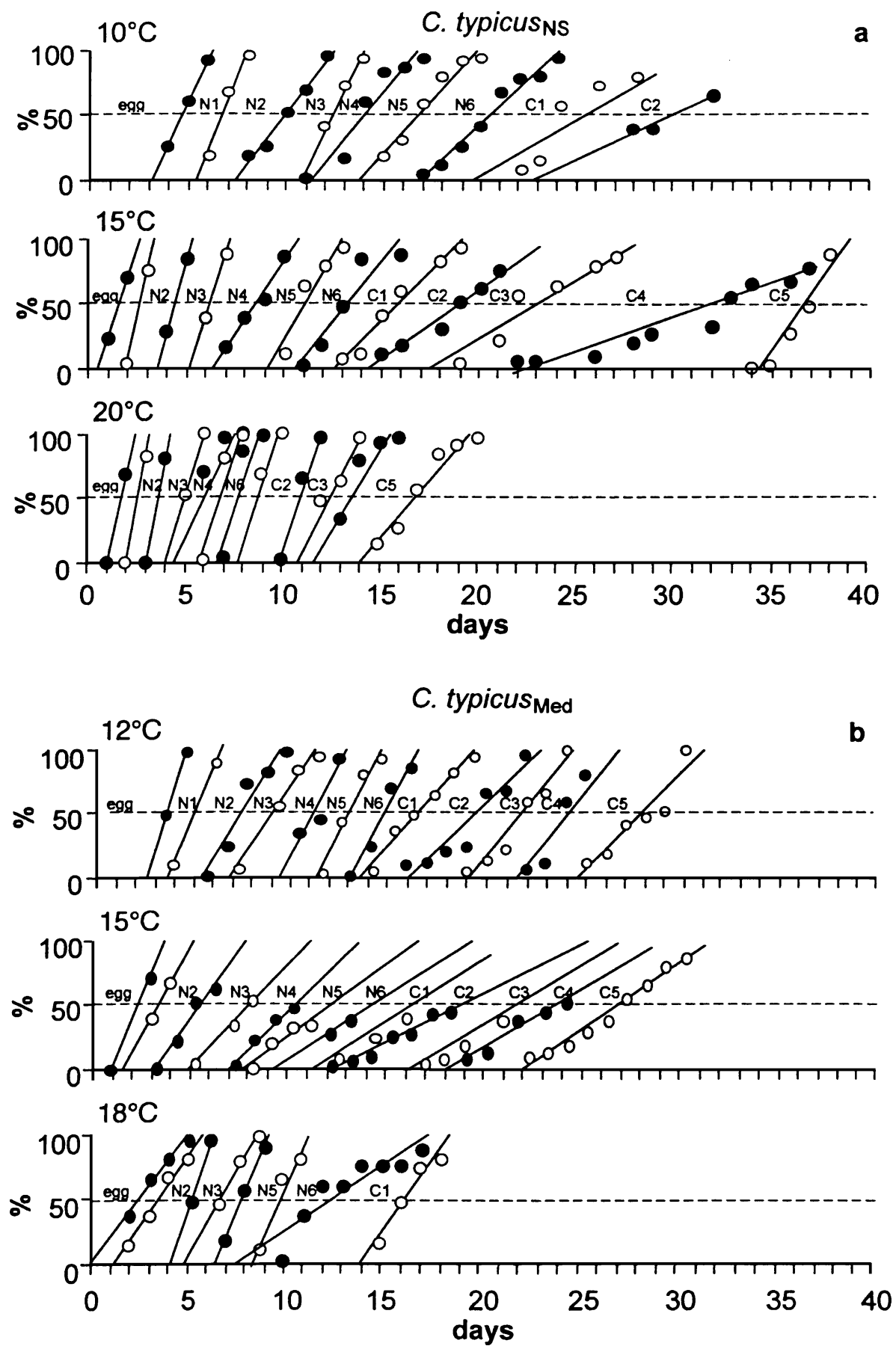


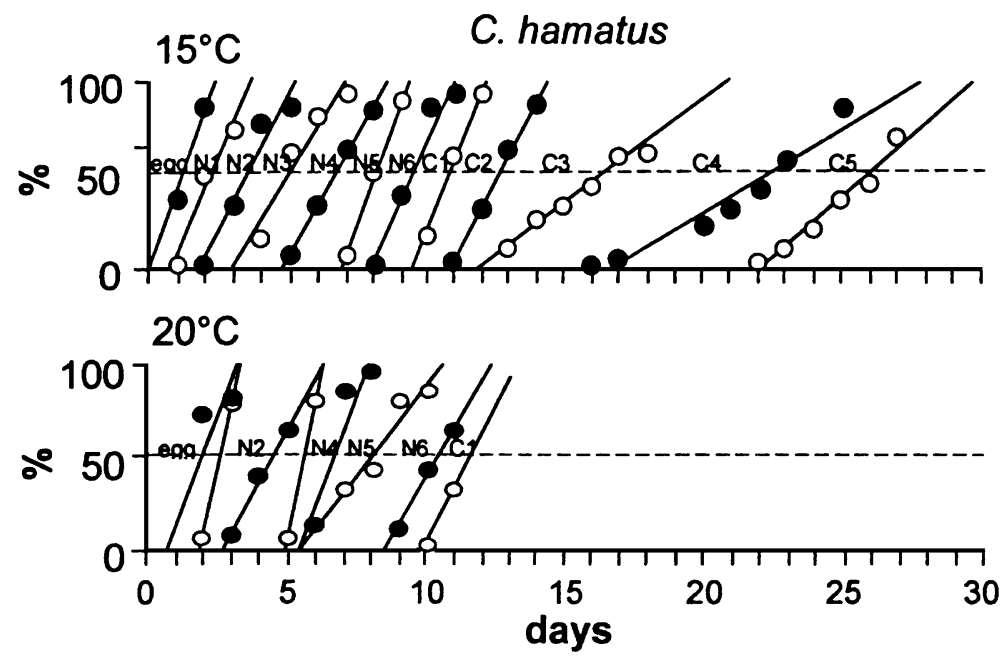

Fig. 12. C. hamatus. Stage composition in cohorts reared at different temperatures. For annotations see Fig. 11.

Instars of C. typicus Med tended to develop more rapidly than those of C. typicus NS $_{\mathrm{N}}$ at 12 and $15^{\circ} \mathrm{C}$ (Fig. $14 \mathrm{a}-\mathrm{c}$, Table 5), but not at $18{ }^{\circ} \mathrm{C}$ when the culture broke down (Fig. 14c). At 15 and at $12{ }^{\circ} \mathrm{C}$, the generation time of $C$. typicus $s_{\text {Med }}$ was shorter than that of $C$. typicus $_{\mathrm{NS}}$ at $15^{\circ} \mathrm{C}$ (Table 4). Equiproportional development was found in C. typicus Med $_{\text {at }}$ at

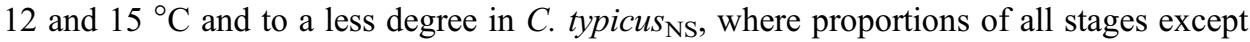
$\mathrm{CV}$ were greater at $20{ }^{\circ} \mathrm{C}$ than at $15{ }^{\circ} \mathrm{C}$. Relative stage duration compared between study sites showed no equiproportionality (Table 6). Mortality rates of nauplii ${ }_{\mathrm{NS}}$ were lowest at $15{ }^{\circ} \mathrm{C}$ with 0.014 day $^{-1}$, increasing both at 10 and $18{ }^{\circ} \mathrm{C}$ to 0.086 and 0.088 day $^{-1}$, respectively (Table 3 ). The opposite occurred for copepodites ${ }_{N S}$, which had higher mortality rates at $15{ }^{\circ} \mathrm{C}\left(0.116\right.$ day $\left.^{-1}\right)$ than at $20{ }^{\circ} \mathrm{C}\left(0.012\right.$ day $\left.^{-1}\right)$. Mortality rates of nauplii $_{\text {Med }}$ and copepodites Med were very similar and decreased constantly with increasing temperature from 0.1 day $^{-1}$ at $12{ }^{\circ} \mathrm{C}$ to 0.001 day $^{-1}$ at $18{ }^{\circ} \mathrm{C}$ (Table 3).

\subsubsection{C. typicus and C. hamatus in the North Sea}

FTT differed between both congeners (Table 5). C. typicus was more sensitive to low temperatures. In $C$. hamatus, in contrast, mortality was much higher at any temperature $>5{ }^{\circ} \mathrm{C}$.

The temperature range of egg production was the same in both species $\left(2-25^{\circ} \mathrm{C}\right)$, but optima were different. C. typicus had highest egg production rates at $20{ }^{\circ} \mathrm{C}(54$ eggs female ${ }^{-1}$ day $\left.^{-1}\right), C$. hamatus at $12.5^{\circ} \mathrm{C}\left(12.1\right.$ eggs female ${ }^{-1}$ day $\left.^{-1}\right)$ with high standard deviations at 15 and $20{ }^{\circ} \mathrm{C}$ (Fig. 6a,b).

Fig. 11. C. typicus. Stage composition in cohorts reared at different temperatures. Symbols show cumulative percentage of the population having completed a given moult versus time. Open and closed circles alternate for adjacent stages. Indices ${ }_{\mathrm{NS}}$ and $\mathrm{Med}=$ North Sea and Mediterranean. 

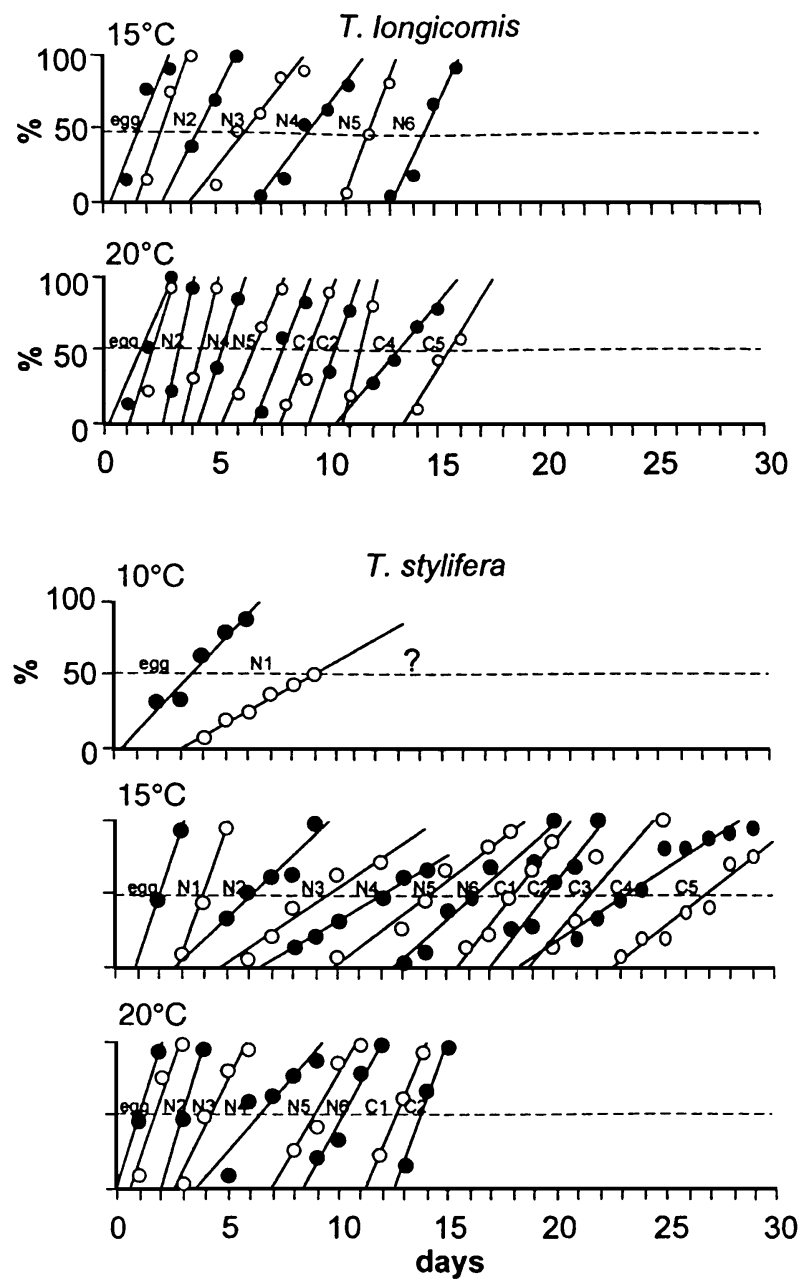

Fig. 13. T. longicornis and T. stylifera. Stage composition in cohorts reared at different temperatures. For annotations see Fig. 11.

Egg development times between congeners were nearly the same between 10 and $20{ }^{\circ} \mathrm{C}$. At lower temperatures, $C$. typicus eggs had shorter development times. Embryos of $C$. typicus developed most quickly at $25^{\circ} \mathrm{C}$, those of $C$. hamatus at $22.5{ }^{\circ} \mathrm{C}$ with a prolonged development at $25{ }^{\circ} \mathrm{C}$ (Fig. 9a,b). Hatching success was more variable in C. hamatus (Fig. 10a,b).

Stage development showed similar patterns in both species with short stage durations in nauplii and slowest development in late copepodites (Fig. 14b,d). Nauplii of C. hamatus developed more rapidly ( 9.4 days) than nauplii of $C$. typicus $\left(13.2\right.$ days) at $15^{\circ} \mathrm{C}$ from egg to $\mathrm{CI}$, respectively (Table 4). At $20^{\circ} \mathrm{C}$, development of eggs, NII and NVI of C. hamatus was retarded as compared to $15^{\circ} \mathrm{C}$ and thus was slower than in C. typicus (Fig. 14c,e). 
Table 3

Stage durations (day) and mortality rates $\left(\right.$ day $\left.^{-1}\right)$ of C. typicus, C. hamatus, T. longicornis and T. stylifera at different temperatures

\begin{tabular}{|c|c|c|c|c|c|c|c|c|c|c|c|c|c|}
\hline & \multicolumn{7}{|c|}{ North Sea } & \multicolumn{6}{|c|}{ Mediterranean } \\
\hline & \multicolumn{3}{|c|}{ C. typicus } & \multicolumn{2}{|c|}{ C. hamatus } & \multicolumn{2}{|c|}{ T. longicornis } & \multicolumn{3}{|c|}{ C. typicus } & \multicolumn{3}{|c|}{ T. stylifera } \\
\hline & $10^{\circ} \mathrm{C}$ & $15^{\circ} \mathrm{C}$ & $20^{\circ} \mathrm{C}$ & $15^{\circ} \mathrm{C}$ & $20^{\circ} \mathrm{C}$ & $15^{\circ} \mathrm{C}$ & $20^{\circ} \mathrm{C}$ & $12^{\circ} \mathrm{C}$ & $15^{\circ} \mathrm{C}$ & $18{ }^{\circ} \mathrm{C}$ & $10^{\circ} \mathrm{C}$ & $15^{\circ} \mathrm{C}$ & $20{ }^{\circ} \mathrm{C}$ \\
\hline \multicolumn{14}{|l|}{ Instar } \\
\hline Egg & 4.70 & 1.54 & 0.72 & 1.21 & 1.93 & 1.69 & 1.75 & 3.28 & 2.32 & 1.56 & 3.47 & 1.94 & 1.05 \\
\hline NI & 2.04 & 1.08 & 0.89 & 1.04 & 0.66 & 0.98 & 0.50 & 1.48 & 1.39 & 0.92 & 5.35 & 1.60 & 0.67 \\
\hline NII & 3.12 & 1.74 & 1.02 & 1.26 & 1.83 & 1.68 & 1.13 & 2.55 & 2.24 & 1.51 & & 2.30 & 1.30 \\
\hline NIII & 2.50 & 1.82 & 1.36 & 1.50 & 1.16 & 2.08 & 0.93 & 0.97 & 2.06 & 1.03 & & 2.81 & 1.18 \\
\hline NIV & 1.58 & 2.30 & 1.02 & 1.60 & 1.05 & 2.79 & 0.92 & 1.28 & 1.65 & 1.80 & & 1.66 & 2.20 \\
\hline NV & 2.76 & 2.57 & 0.79 & 1.43 & 1.27 & 2.86 & 1.46 & 1.69 & 1.52 & 2.04 & & 1.54 & 2.47 \\
\hline NVI & 3.79 & 2.14 & 0.95 & 1.35 & 2.46 & 2.65 & 1.27 & 2.63 & 1.71 & 2.39 & & 1.70 & 1.28 \\
\hline CI & 4.87 & 2.59 & 1.15 & 1.50 & 1.25 & & 1.14 & 2.71 & 2.30 & 4.00 & & 1.70 & 2.51 \\
\hline CII & 4.08 & 3.22 & 1.00 & 1.73 & & & 1.21 & 1.69 & 2.68 & & & 1.44 & 1.04 \\
\hline CIII & & 3.98 & 2.56 & 4.06 & & & 1.15 & 2.86 & 2.78 & & & 2.76 & \\
\hline CIV & & 9.43 & 1.13 & 5.31 & & & 1.67 & 2.65 & 2.52 & & & 2.11 & \\
\hline $\mathrm{CV}$ & & 4.41 & 3.27 & 4.05 & & & 2.31 & 3.48 & 3.80 & & & 2.65 & \\
\hline \multicolumn{14}{|c|}{ Mortality $\left(\right.$ day $\left.^{-1}\right)$} \\
\hline $\mathrm{Egg}-\mathrm{CI}$ & 0.050 & 0.030 & 0.012 & 0.038 & 0.165 & 0.150 & 0.172 & 0.101 & 0.034 & 0.001 & & 0.092 & 0.339 \\
\hline CI-adult & & 0.172 & 0.012 & 0.045 & & & 0.103 & 0.102 & 0.055 & & & -0.020 & \\
\hline
\end{tabular}

Development times were equiproportional in both congeners at $15{ }^{\circ} \mathrm{C}$ (Table 6). Mortality rates of nauplii and copepodites were the same in $C$. hamatus, while copepodites of $C$. typicus suffered much higher mortality than nauplii (Table 3). Mortality increased considerably from 15 to $20{ }^{\circ} \mathrm{C}$ both in C. hamatus and C. typicus nauplii (Table 3).

\subsubsection{T. longicornis (North Sea) and T. stylifera (Mediterranean)}

The two Temora species considered here showed quite different FTT (Table 5). $T$. stylifera females stayed alive and maintained reproduction up to $30{ }^{\circ} \mathrm{C}$ (Figs. 5e and 6e), whereas T. longicornis could not withstand temperatures above $22.5{ }^{\circ} \mathrm{C}$ (Fig. $4 \mathrm{c}$ ). Optimal survival of $T$. stylifera occurred at 10 and $15{ }^{\circ} \mathrm{C}$, while 2 and $5{ }^{\circ} \mathrm{C}$ were lethal. The mortality observed at $20^{\circ} \mathrm{C}$ can be considered as suspect (Fig. 4e). T. longicornis showed low mortality between 0 and $22.5^{\circ} \mathrm{C}$ without any clear optimum (Fig. 4c).

RTR also differed between the Temora congeners. Egg production of $T$. longicornis ranged between 5 and 10 eggs female ${ }^{-1}$ day $^{-1}$ from 0 to $15^{\circ} \mathrm{C}$, peaked at $20{ }^{\circ} \mathrm{C}$ with 18.8 eggs female ${ }^{-1}$ day $^{-1}$ and decreased sharply at $22.5^{\circ} \mathrm{C}$ (Fig. 6c). In contrast, $T$.

\footnotetext{
Notes to Table 4:

$\mathrm{NS}=$ North Sea, $\mathrm{M}=$ Mediterranean, $\mathrm{A}=$ Atlantic.

I.g. = Isochrysis galbana, H.e. = Hymenomonas elongata, T.s. = Tetraselmis suecica, D.t. = Dunalliella tertiolecta, T.w. $=$ Thalassiosira weissflogii, T.r. $=$ Thalassiosira rotula, R.b. $=$ Rodomonas baltica, R.sp. $=$ Rhodomonas sp., O.m. = Oxyrrhis marina.
} 
Table 4

Egg production rates (EPR) and development times of C. typicus, C. hamatus, T. longicornis and T. stylifera

\begin{tabular}{|c|c|c|c|c|c|c|c|c|c|}
\hline Species & & $T\left[{ }^{\circ} \mathrm{C}\right]$ & Food & EPR & Egg-CI [day] & CI-adult [day] & Generation time [day] & Definition & Reference \\
\hline \multirow[t]{20}{*}{ C. typicus } & NS & 2 & I.g./H.e. & 2.9 & & & & & this study \\
\hline & NS & 5 & I.g./H.e. & 10.3 & & & & & this study \\
\hline & M & 5 & I.g./H.e. & 5.0 & & & & & this study \\
\hline & NS & 7.5 & I.g./H.e. & 15.8 & & & & & this study \\
\hline & $\mathrm{M}$ & 8 & I.g./H.e. & & & & & & this study \\
\hline & NS & 10 & I.g./H.e. & 28.7 & 19.9 & & & egg-adult & $\begin{array}{l}\text { this study } \\
\text { this study }\end{array}$ \\
\hline & A & 10 & T.w. & & 23.0 & 26.0 & 49.0 & egg-adult & Smith and Lane, 1985 \\
\hline & $\mathrm{M}$ & 12 & I.g./H.e. & & 13.9 & 13.4 & 27.3 & egg-adult & this study \\
\hline & NS & 15 & I.g./H.e. & 27.8 & 13.2 & 23.6 & 36.8 & egg-adult & this study \\
\hline & $\mathrm{M}$ & 15 & I.g./H.e. & 20.0 & 12.9 & 14.1 & 27.0 & egg-adult & this study \\
\hline & NS & 17 & R.b./O.m. & & $5.8 \mathrm{NII}-\mathrm{CI}$ & 8.9 & 14.6 & NII-adult & Fryd et al., 1991 \\
\hline & $\mathrm{M}$ & 18 & I.g./H.e. & & 11.3 & & & egg-adult & this study \\
\hline & $\mathrm{A}$ & $18-19$ & mixed & & $9-11$ & $10-12$ & $19-23$ & egg-adult & Lawson and Grice, 1970 \\
\hline & $\mathrm{M}$ & $18-20$ & in situ & & 8.0 & 20.0 & 28.0 & egg-adult & Gaudy, 1976 \\
\hline & NS & 20 & I.g./H.e. & 64.7 & 7.3 & 9.1 & 15.9 & egg-adult & this study \\
\hline & $\mathrm{M}$ & 20 & I.g./H.e. & 34.1 & & & & & this study \\
\hline & $\mathrm{M}$ & 20 & T.s. & & & & 25.0 & egg-maturity & Le Ruyet-Person et al., 1975 \\
\hline & NS & 22.5 & I.g./H.e. & 44.3 & & & & & this study \\
\hline & NS & 25 & I.g./H.e. & 28.1 & & & & & this study \\
\hline & $\mathrm{M}$ & 25 & I.g./H.e. & 20.7 & & & & & this study \\
\hline \multirow[t]{11}{*}{ C. hamatus } & NS & 2 & I.g./H.e. & 4.6 & & & & & this study \\
\hline & NS & 5 & I.g./H.e. & 3.3 & & & & & this study \\
\hline & NS & 10 & I.g./H.e. & 7.6 & & & & & this study \\
\hline & & $\approx 7-10$ & in situ & & & & $\approx 25$ & egg-adult & McLaren, 1978 \\
\hline & & $\approx 10-14$ & in situ & & & & $\approx 20$ & egg-adult & McLaren, 1978 \\
\hline & NS & 12.5 & I.g./H.e. & 12.1 & & & & & this study \\
\hline & NS & 15 & I.g./H.e. & 7.1 & 9.4 & 16.7 & 26.0 & egg-adult & this study \\
\hline & NS & 17 & R.b./O.m. & & $7.3 \mathrm{NII}-\mathrm{CI}$ & 8.8 & 16.1 & NII-adult & Fryd et al., 1991 \\
\hline & NS & 20 & I.g./H.e. & 8.3 & 10.4 & & & egg-adult & this study \\
\hline & NS & 20 & T.s. & & & & 22.0 & egg-maturity & Le Ruyet-Person et al., 1975 \\
\hline & NS & 25 & I.g./H.e. & 7.6 & & & & & this study \\
\hline
\end{tabular}




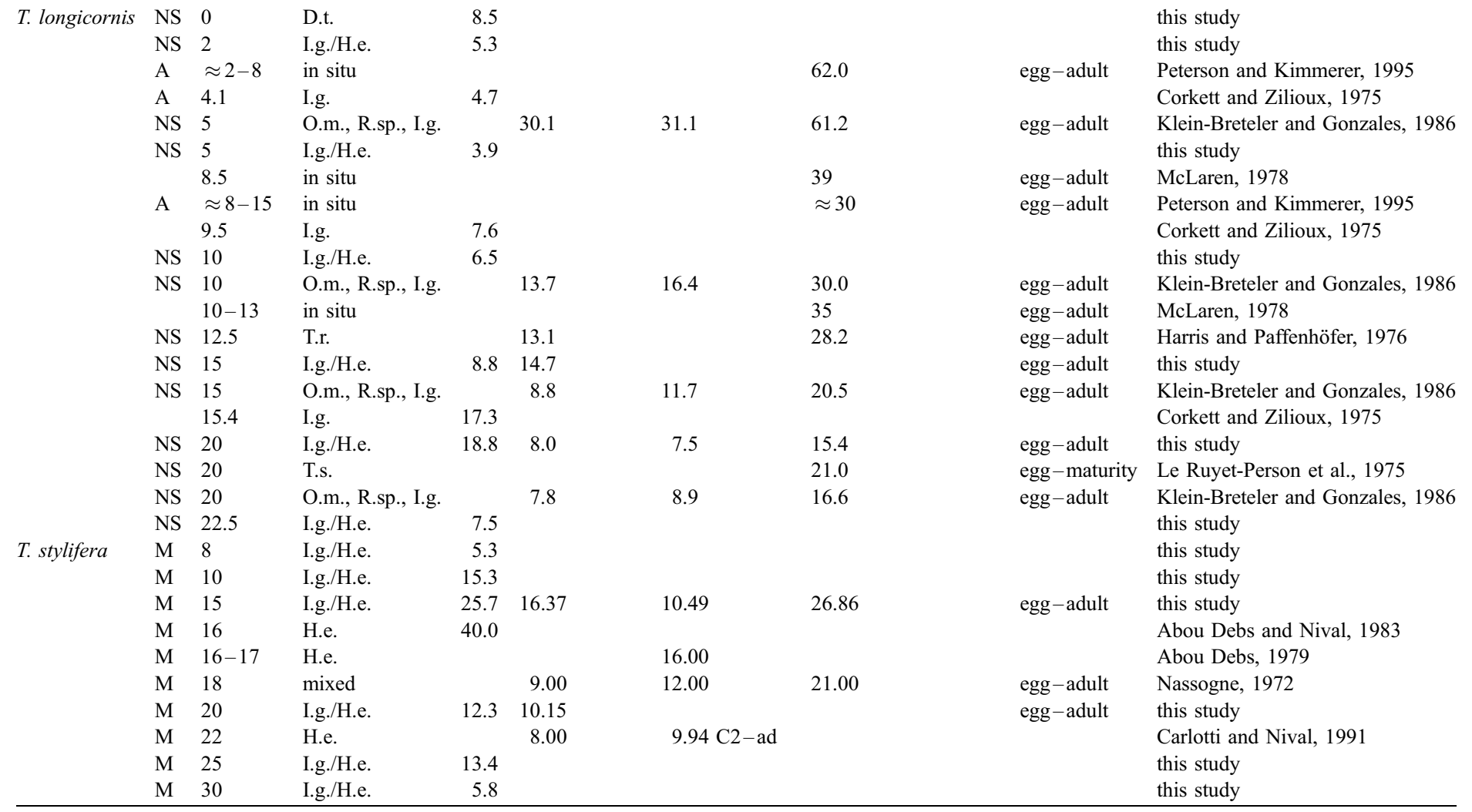




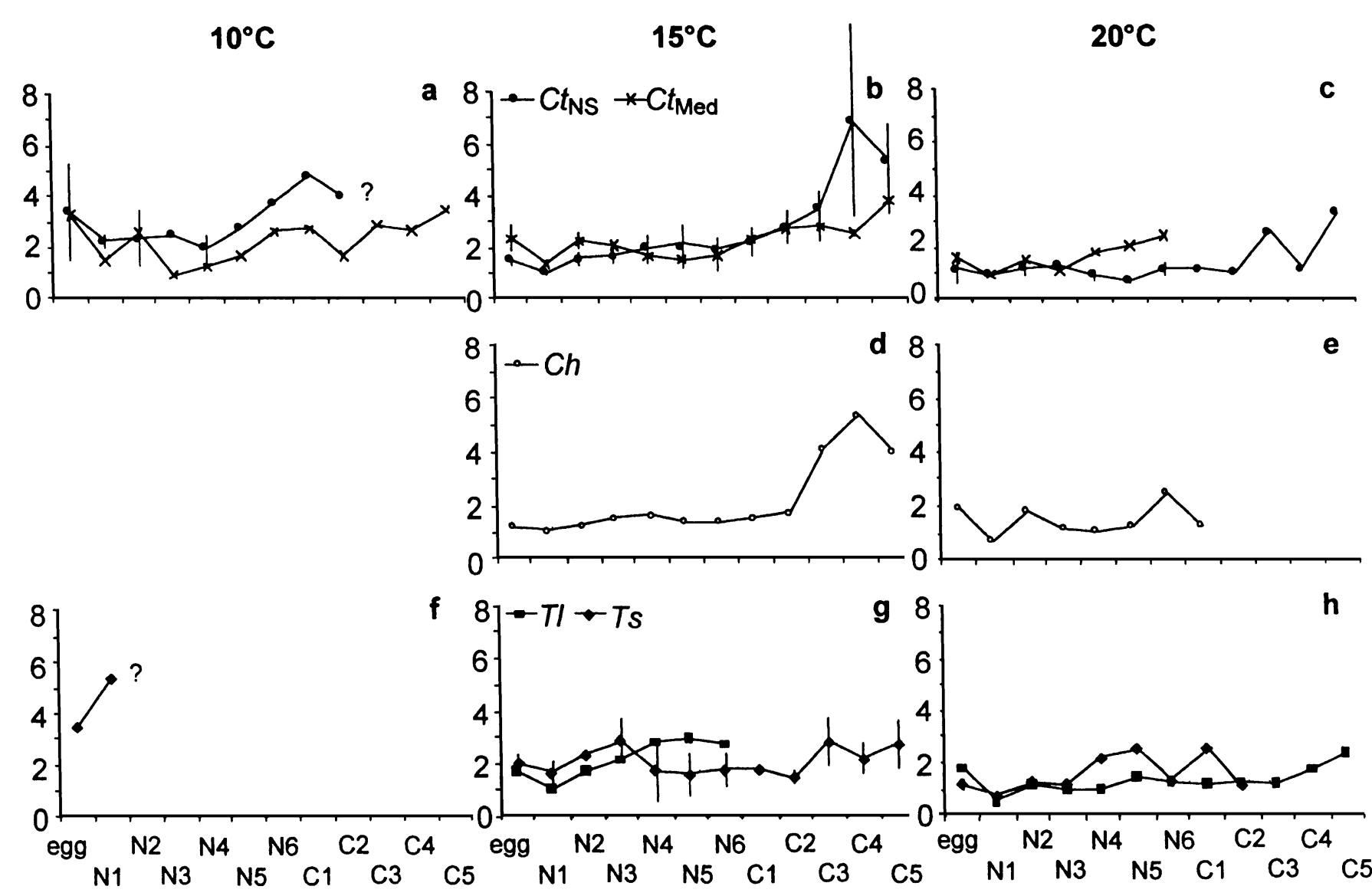


Table 5

Synthesis of results from incubations in a temperature gradient from 0 to $35^{\circ} \mathrm{C}$

\begin{tabular}{|c|c|c|c|c|c|c|}
\hline \multirow[t]{2}{*}{ Species } & \multicolumn{2}{|l|}{ FTT } & \multicolumn{2}{|l|}{ RTR } & \multicolumn{2}{|l|}{ ETR } \\
\hline & Lethal $\left({ }^{\circ} \mathrm{C}\right)$ & Optimum $\left({ }^{\circ} \mathrm{C}\right)$ & Range $\left({ }^{\circ} \mathrm{C}\right)$ & Optimum $\left({ }^{\circ} \mathrm{C}\right)$ & Range $\left({ }^{\circ} \mathrm{C}\right)$ & Optimum $\left({ }^{\circ} \mathrm{C}\right)$ \\
\hline C. typicu $_{\mathrm{NS}}$ & 30 & $5-10$ & $2-25$ & 20 & $5-25$ & 25 \\
\hline C. hamatus & 25 & 5 & $2-25$ & 12.5 & $2-25$ & 22.5 \\
\hline C. typicus $_{\mathrm{Med}}$ & $2 / 30$ & $10-15$ & $5-25$ & 20 & $5-28$ & 25 \\
\hline T. longicornis & 25 & $2-22.5$ & $0-22.5$ & 20 & $0-22.5$ & 22.5 \\
\hline T. stylifera & $2 / 30$ & $10-15$ & $8-30$ & 15 & $10-28$ & 28 \\
\hline
\end{tabular}

Female thermal tolerance (FTT), reproductive thermal response (RTR) and embryonic thermal response (ETR).

stylifera produced no eggs below $8{ }^{\circ} \mathrm{C}$; the optimum occurred at $15{ }^{\circ} \mathrm{C}$ with 25.7 eggs female $^{-1}$ day $^{-1}$, at higher temperatures the egg production rates declined (Fig. 6e).

ETR showed different tolerance limits for T. longicornis $\left(0-22.5^{\circ} \mathrm{C}\right)$ and T. stylifera $\left(10-28{ }^{\circ} \mathrm{C}\right.$; Table 5). The Belehrádek function of $T$. stylifera had a similar curvilinearity as that of T. longicornis in March, but was displaced towards higher temperatures (Fig. 9c,e). Cold temperatures inhibited development of T. stylifera embryos. No nauplii hatched below $10{ }^{\circ} \mathrm{C}$ and the proportion of viable eggs increased with temperature from 10 to 20 ${ }^{\circ} \mathrm{C}$ and slightly decreased at $25{ }^{\circ} \mathrm{C}$ (Fig. 10e). In contrast, hatching success of $T$. longicornis was high at all temperatures between 2 and $22.5^{\circ} \mathrm{C}$, but no eggs developed beyond this limit (Fig. 10c).

A seasonal comparison of ETR was available for T. longicornis (Fig. 9c). Eggs developed relatively quickly at low temperatures in summer, but slower in winter. In March 1996, embryos needed more time to hatch at a given temperature than in June 1996 $(p<0.0001)$, and than from June to September $1999(p<0.0001)$. The difference was less significant between June 1996 and June to September $1999(p<0.01)$.

Stage durations of nauplii were slightly shorter in T. longicornis than in T. stylifera at 15 and $20{ }^{\circ} \mathrm{C}$ (Table 3). Development times of T. longicornis decreased from 15 to $20^{\circ} \mathrm{C}$, while NIV, NV and CI of T. stylifera developed more quickly at $15^{\circ} \mathrm{C}$ than at $20{ }^{\circ} \mathrm{C}$ (Fig. $14 \mathrm{f}-\mathrm{h}$ ). At $10{ }^{\circ} \mathrm{C}$, no development was observed beyond NI in T. stylifera (Fig. 14f). Relative development times of both congeners were equiproportional (Table 6). Mortality rates of $T$. longicornis were 0.150 and $0.172 \mathrm{day}^{-1}$ for nauplii at 15 and $20{ }^{\circ} \mathrm{C}$,

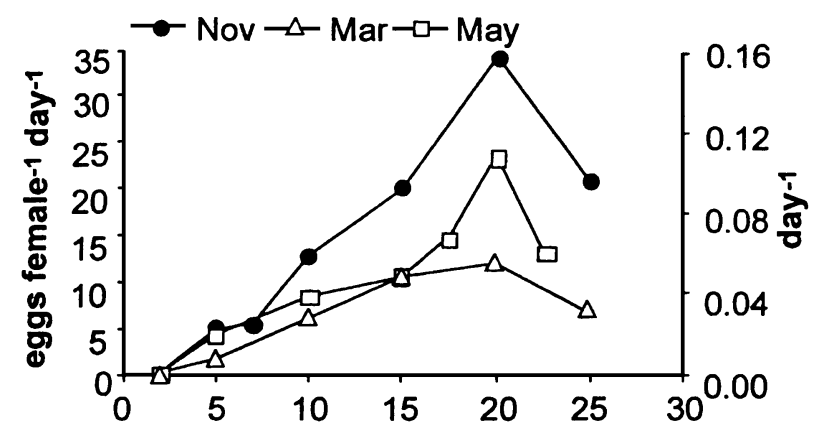

Fig. 15. Seasonal variation of egg production of C. typicus in the Mediterranean. 
Table 6

Proportion of total development time (egg-laying to adult) spent in each stage (= cumulative median development time/generation time)

\begin{tabular}{llllllll}
\hline & $C t_{\mathrm{NS}}$ & $C t_{\mathrm{NS}}$ & $C t_{\text {Med }}$ & $C t_{\text {Med }}$ & $C h$ & $T l$ & $T s$ \\
\cline { 2 - 7 } & $15{ }^{\circ} \mathrm{C}$ & $20{ }^{\circ} \mathrm{C}$ & $12{ }^{\circ} \mathrm{C}$ & $15{ }^{\circ} \mathrm{C}$ & $15{ }^{\circ} \mathrm{C}$ & $20{ }^{\circ} \mathrm{C}$ & $15{ }^{\circ} \mathrm{C}$ \\
\hline NI & 0.04 & 0.05 & 0.12 & 0.09 & 0.05 & 0.11 & 0.09 \\
NII & 0.07 & 0.10 & 0.17 & 0.14 & 0.09 & 0.15 & 0.14 \\
NIII & 0.12 & 0.17 & 0.27 & 0.22 & 0.13 & 0.22 & 0.22 \\
NIV & 0.17 & 0.25 & 0.30 & 0.30 & 0.19 & 0.28 & 0.30 \\
NV & 0.23 & 0.32 & 0.35 & 0.36 & 0.25 & 0.34 & 0.36 \\
NVI & 0.30 & 0.37 & 0.41 & 0.41 & 0.31 & 0.43 & 0.41 \\
CI & 0.36 & 0.43 & 0.51 & 0.48 & 0.36 & 0.52 & 0.48 \\
CII & 0.43 & 0.50 & 0.61 & 0.56 & 0.42 & 0.59 & 0.56 \\
CIII & 0.51 & 0.56 & 0.67 & 0.66 & 0.48 & 0.67 & 0.66 \\
CIV & 0.62 & 0.72 & 0.78 & 0.76 & 0.64 & 0.74 & 0.76 \\
CV & 0.88 & 0.79 & 0.87 & 0.86 & 0.84 & 0.85 & 0.86 \\
Adult & 1.00 & 1.00 & 1.00 & 1.00 & 1.00 & 1.00 & 1.00 \\
\hline
\end{tabular}

$C t=C$. typicus, $C h=C$. hamatus, $T l=T$. longicornis, $T s=T$. stylifera .

respectively, and $0.103 \mathrm{day}^{-1}$ for copepodites at $20{ }^{\circ} \mathrm{C}$ (Table 3). T. stylifera had very high death rates in nauplii at $20{ }^{\circ} \mathrm{C}\left(0.339\right.$ day $\left.^{-1}\right)$ prior to collapse of the culture and thus were considered as artefact. At $15{ }^{\circ} \mathrm{C}$, nauplii mortality was $0.092 \mathrm{day}^{-1}$. Negative mortality was observed in copepodites (Table 3), due to the sampling technique, i.e. a misrepresentation of specimens in the subsamples, which is attributed to inefficient mixing of the culture before sampling.

\section{Discussion}

\subsection{General responses of life history traits}

Temperature affected all phases of the copepod life cycle considered here. Like in many poikilotherms, temperature response was not fixed but showed a suite of adaptational mechanisms. Response patterns to varying temperatures were (1) optimum curves of survival and reproduction over a wide range of temperatures, (2) Belehrádek functions of embryonic development and (3) equiproportional development of instars. These responses often varied between congener species and locations.

\subsubsection{Thermal tolerance limits}

The thermal ranges were rather similar in all parameters considered (Table 5). However, in some cases, a slight decrease of tolerance was observed in subsequent life phases, e.g. in T. stylifera whose temperature range was wider for female survival than for reproduction and even narrower for embryonic development.

Heat death occurred in all species, except T. stylifera, at $30{ }^{\circ} \mathrm{C}$ or below, indicating that this temperature represents a threshold beyond which a selective measure is necessary to ascertain survival, e.g. the production of heat shock proteins reported for various marine 
organisms (Burdon, 1987; Hofmann, 1999). Depression of development rate (i.e. increasing development time) as an expression of physiological inefficiency at the upper end of a species' thermal range has been reported for embryos of $A$. clausi, $T$. stylifera and $C$. chierchiae (Landry, 1975; Bernard, 1971). We also observed prolonged embryonic duration at $25^{\circ} \mathrm{C}$ or above, both in the North Sea (C. hamatus) and in the Mediterranean (C. typicus).

Cold death occurred below $5{ }^{\circ} \mathrm{C}$ in warm-acclimated individuals of the Mediterranean. The lower temperature limit of the boreal species was missed during this study and may be around the freezing point of seawater.

\subsubsection{Optimum curves}

Survival and reproduction rate are optimum functions of temperature under saturating food conditions, increasing up to the optimum and decreasing beyond (Corkett and Zilioux, 1975; Uye, 1981; Kimoto et al., 1986). All species investigated followed this pattern, with differences in tolerance limits and optimal temperatures (Table 5). The optima of reproduction differed between the congeners $C$. typicus and C. hamatus, while intraspecific variability was restricted to a shift in the lower tolerance limit of $C$. typicus from different locations. The Temora congeners clearly distinguished in their optima and tolerance limits. T. longicornis showed increasing egg production rates between between 0 and $20{ }^{\circ} \mathrm{C}$, matching the values reported by Corkett and Zilioux (1975) (Table 4). T. stylifera, in contrast, showed highest reproductive activity at $15^{\circ} \mathrm{C}$ with declining rates at higher and lower temperatures according to Abou-Debs and Nival (1983) (Table 4).

\subsubsection{Belehrádek curves}

Belehrádek's function $D=a(T-\alpha)^{b}$ has been widely used in the literature to describe the temperature response of development. In our study, embryonic development followed Belehrádek functions in all species studied (Table 2). The constant $b$ is assumed to be - 2.05 for all copepod species (McLaren et al., 1969; Landry, 1975; Ambler, 1985) and therefore was also used in our equations. The curve of $C$. typicus $_{\mathrm{NS}}$ corresponded to that of C. typicus $_{\text {Med }}$ in autumn, while the equation derived by McLaren et al. (1989) from Atlantic specimens matched best with our equation from May (Table 2). Abou-Debs and Nival (1983) presented to equations for T. stylifera embryos from spring and autumn. Our curve from November matched their values at temperatures $>15{ }^{\circ} \mathrm{C}$, but did not confirm the very high "biological zero" they suggest for the development of offspring of warmacclimated parents.

Embryonic development time has been primarily attributed to egg size both on a seasonal and latitudinal scale (Corkett, 1972; Lonsdale and Levinton, 1985), with larger eggs from larger females having lower metabolic rates than smaller eggs due to lower oxygen diffusion rates. During our study, egg-size was almost constant throughout the study period in all species (Halsband-Lenk, unpublished). Therefore, parental influences due to acclimation (Landry, 1975) and heredity (Fujisawa, 1995) seem more likely to influence ETR in this case.

A fast embryonic development seems advantageous to reduce predation pressure on motionless eggs, which increases with the time needed until hatching (Ohman, 1986). Moreover, a long non-swimming phase denotes a high risk of loss below the euphotic zone 
or to the sediment in shallow shelf regions. Thus, short embryonic duration at low temperature was observed in embryos of T. longicornis and C. typicus ${ }_{\mathrm{NS}}$. C. hamatus, in contrast, has established other adaptations to low temperature, switching from the production of subitanous eggs to diapause eggs in fall (Grice and Marcus, 1981).

\subsubsection{Equiproportional development}

The thermal response of post-embryonic development followed the patterns described by Landry (1983): the first non-feeding stage (NI) developed quickly, while the first feeding stage (NII) was prolonged. Thereafter, development in some experiments approximated isochronal development (e.g. C. hamatus at $15^{\circ} \mathrm{C}$ and T. longicornis at $20^{\circ} \mathrm{C}$ ). The late copepodites CIV (C. typicus $\mathrm{NS}_{\mathrm{N}}$ and C. hamatus) or CV (C. typicus $\mathrm{Med}, T$. stylifera, T. longicornis) again had increased stage durations, probably due to formation of reproductive products prior to adulthood (Fryd et al., 1991). Equiproportional development as defined by Corkett and McLaren (1984) means that the relative proportion of the generation time spent in each stage is the same regardless temperature. C. typicus was reported to follow this rule (Fryd et al., 1991), and we found equiproportional development both in C. typicus $s_{\mathrm{NS}}$ and C. typicus $_{\mathrm{Med}}$ (Table 6). Relative development times did not match in $C$. typicus populations from different locations, but those of the congeners $C$. typicus $s_{\mathrm{NS}}$ and $C$. hamatus and of T. longicornis and T. stylifera were very close (Table 6).

Literature and our results showed shortest generation time at $20{ }^{\circ} \mathrm{C}$ for all species investigated (Klein Breteler et al., 1994; Klein Breteler and Gonzales, 1986). However, we found that stage duration did not consistently decrease with increasing temperature. This might indicate thermal stress of some specific developmental stages at high temperatures in the boreal populations $C$. hamatus and T. longicornis, but also in both Mediterranean populations.

Generation time at a given temperature was similar for all species (Table 4) and fell in the range of the temperature function presented by Huntley and Lopez (1992, Fig. 3).

\subsection{Adaptational responses}

\subsubsection{Seasonal variations}

Seasonal variations in the temperature response of reproduction, investigated here for C. typicus $_{\mathrm{Med}}$, were restricted to the absolute number of eggs produced, reflecting different reproductive potential of females in different seasons, while RTR remained constant. The same was observed for T. stylifera (Abou-Debs and Nival, 1983), which produced more eggs in March than in October at three experimental temperatures, while the optimum remained at $16{ }^{\circ} \mathrm{C}$. The variations in absolute egg numbers might be due to different age structure of the population (proportion of spent females), different nutritional state and/or body size of females (Uye, 1981).

T. longicornis embryos showed seasonal alterations of ETR. Eggs laid in March 1996 during a cold winter developed more slowly at a given temperature than in summer. Many authors observed shorter egg development times in eggs of warm-acclimated parents (Ambler, 1985; Tester, 1982), while Landry (1975) observed the opposite: coldacclimated eggs of $A$. clausi hatched faster at a given temperature than their counterparts 
in summer. He concluded that enhanced metabolic rates are an acclimation response of cold-adapted embryos to high temperatures. Abou-Debs and Nival (1983) found much slower development at low temperatures in eggs produced in autumn than in spring and concluded that warm acclimated embryos have a much higher "biological zero", while those produced in cold spring matched the development times of Atlantic species. Hart and McLaren (1978) emphasized the opposing effects of long-term (seasonal) and shortterm acclimation responses suggesting that seasonal temperature compensation is overridden by size effects and heredity of embryonic duration in the field. Besides adaptation effects, both geographical and seasonal differences in ETR might additionally reflect varying nutritional investment of females in the yolk of their eggs, depending on the quantity and quality of available food (Lonsdale and Levinton, 1985; Jónasdóttir, 1994).

\subsubsection{Regional variations}

The Belehrádek curves of cold-acclimated North Sea embryos were displaced by about $5^{\circ}$ towards lower temperatures in relation to the curves of their Mediterranean congeners (Fig. 9). Post-embryonic stages of C. typicus tended to develop more quickly in the Mediterranean than in the North Sea at all temperatures investigated (Fig. 14), suggesting an influence of body size as postulated by Vidal (1980), who stated that smaller individuals have shorter stage durations than larger ones.

\subsection{Geographic distribution and thermal response}

When our results are compared with field data, a mismatch between RTR in the laboratory and reproduction peaks in the field became apparent. While the temperature optima of egg-laying differed considerably between $C$. hamatus and T. longicornis in our experiments, in the North Sea their reproduction peaks occurred simultaneously in spring at $5-10{ }^{\circ} \mathrm{C}$ in situ temperature (van Rijswijk et al., 1989; Halsband and Hirche, 2001). Egg production rate was controlled by body size which in turn was related to temperature (Halsband and Hirche, 2001). Analogously, in the Bay of Villefranche in situ reproduction

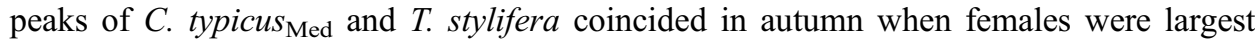
(Halsband-Lenk et al., 2001), while temperature optima in the laboratory were different. There, body size appeared to be less influenced by temperature, eventually due to the narrow annual temperature range. This was different from C. typicus in the Gulf of Naples, where maximal egg production rates were recorded in spring (Ianora and Buttino, 1990). Possibly, autumn temperatures are still too high in that shallower region to favour high reproduction rates in this species.

However, specific temperature preferences of individuals seem to be overridden by body size-related reproductive potential at sea. Body size is negatively related to temperature and consequently, the bigger specimens of $C$. typicus NS $_{\mathrm{N}}$ produced more eggs per day than their smaller counterparts in the Mediterranean, constant egg size provided. Accordingly, similar sized females produced similar numbers of eggs, like T. longicornis and $T$. stylifera. Weight specific egg production eliminated size differences and was similar among congeners. The values were lower than those reviewed by Kiørbœ and Sabatini (1995). 


\subsubsection{Centropages sp.}

The comparison of $C$. typicus in two different temperature regimes shows that the species is eurytherm and could shift its tolerance range dynamically to the temperature window of a specific environment. Thus, this species is most independent of temperature and could establish a wide distribution in the North and Middle Atlantic and adjacent seas. The shift of tolerance towards lower temperatures in the North Sea indicates adaptation and temperature compensation. In how far this shift is genetically fixed, as described for benthic organisms and insects with populations along a latitudinal temperature gradient (Hummel et al., 1997; Dahlhoff and Rank, 2000), needs further investigation.

Regarding the congeners in the North Sea, they showed distinct FTT in our experiments, with $C$. typicus favouring intermediate and $C$. hamatus low temperatures. The optima of RTR were congruent with the temperature ranges they encounter during their successive reproduction periods in the North Sea. Both C. typicus and C. hamatus disappear regularly from the water column in winter, but overwintering strategies are different. $C$. hamatus produces resting eggs, which persist unfavourable conditions in the sediment (Lindley, 1990; Marcus, 1996). C. typicus depends on a recurring input from the Atlantic with the inflow of relatively warm water (Fransz et al., 1991) and thus probably overwinters in more temperate regions like the English Channel (Le-Ruyet Person et al., 1975). Thus, the latitudinal and seasonal distribution patterns of both congeners reflect clearly the temperature limits of their survival and reproduction as revealed during our experiments. While C. typicus occurs in waters from the subarctic to the tropics, $C$. hamatus needs to outlast too cold and too warm conditions outside the water column (Fig. 1).

\subsubsection{Temora $s p$.}

The differences of thermal tolerance between these congeners confirmed the classification as a cold-temperate (T. longicornis) and a warm-temperate species (T. stylifera) and hence their geographic distribution. T. longicornis tolerated the whole temperature range found in the North Sea as expected from its perennial occurrence there. The fact that it could not withstand temperatures $>22.5{ }^{\circ} \mathrm{C}$, explains its absence from warmer environments and its restriction to the northern hemisphere with a southern boundary coinciding with the $20{ }^{\circ} \mathrm{C}$ isotherm of the Atlantic in summer (Lindau, 2001).

T. stylifera, in contrast, was the only species that could survive temperatures $>25{ }^{\circ} \mathrm{C}$, at least in the adult stage, and is accordingly distributed in lower latitudes. Limitation to the north corresponded to the $10{ }^{\circ} \mathrm{C}$ isotherm in winter (Lindau, 2001), representing probably the northern margin of reproductive success, while its occurrence in the English Channel seems more likely a result of advection. However, the thermal optimum of FTT and RTR at $10-15{ }^{\circ} \mathrm{C}$ (Table 5) seemed at first sight surprisingly low, since T. stylifera is considered as a warm-temperate species (Table 1). On the other hand, Abou-Debs and Nival (1983) also found an optimum of RTR at $16{ }^{\circ} \mathrm{C}$ and declining egg production rates towards the temperature extremes of their Mediterranean habitat $\left(13\right.$ and $\left.23{ }^{\circ} \mathrm{C}\right)$. In fact, T. stylifera reproduces mainly during autumnal cooling in the western Mediterranean (Halsband-Lenk et al., 2001). Similar to FTT and RTR, development of some instars was favoured at $15{ }^{\circ} \mathrm{C}$. At $10{ }^{\circ} \mathrm{C}$, no development was possible in culture. Assuming that population development takes place in autumn following the reproduction peak, the preference of a low autumnal 
temperature matched the species' life strategy in situ. Although the limits of temperature tolerance would allow survival and development at higher temperatures, $T$. stylifera tended to prefer intermediate temperatures in the Mediterranean, possibly to avoid resource competition with other copepods (Razouls, 1974). Consequently, thermal tolerance was not necessarily correlated with the optimum.

\subsection{Conclusion}

Despite intraspecific variability, the temperature responses recorded in this study were related to the geographical distribution of the species investigated, with the most northerly species having the lowest minimal temperatures and vice versa. Thus, our results indicate that thermal tolerance of survival, reproduction and development may at least partly determine horizontal and seasonal distribution patterns of these species. Beside temperature, other aspects could be decisive, e.g. other abiotic factors, such as salinity (Gaudy et al., 2000), or biotic factors, e.g. behaviour or ontogeny. Moreover, our results were obtained using mono-algal food cultures, so that the variations in food quantity and quality could possibly modify growth and reproduction rates in the field. Behavioural traits like migration, swimming and escape behaviour may determine mortality patterns (Ohman, 1990) and thus temporal distribution of species, while different life cycle strategies (e.g. undergoing diapause or not) can be responsible for seasonal succession of species.

In a given environment, interactions between species lead to extinction of less adapted species and dominance of better adapted ones, resulting in a specific spatial and temporal species composition. A shift in temperature, either on a latitudinal or a seasonal scale, will modify these interactions and result in a changed combination of species, e.g. as result of climatic changes like global warming. An assessment of the impact of such long-term changes on the zooplankton communities requires more information on how populations respond to critical temperatures, both from an ecological and physiological approach.

\section{Acknowledgements}

C.H.L. was supported by a grant of the French Government (CROUS No. 12478) and within the framework of the PROCOPE Project No. 98179 of DAAD (Germany) and APAPE (France) granted to H.J.H. and F.C. The research work was supported by the programme PNEC-ART2 (1998-1999) and the programme Réseau Diversité Marine (1998-2000) granted to F.C. [RW]

\section{References}

Abou Debs, C., 1979. Aspects de la biologie et de la physiologie de Temora stylifera Dana (copépode calanoïde): éléments du bilan en carbone et azote et optimisation de la fertilité. Ph.D. dissertation. Université Pierre et Marie Curie Paris VI, 300 pp.

Abou Debs, C., Nival, P., 1983. Etude de la ponte et développement embryonnaire en rélation avec la température et la nourriture chez Temora stylifera Dana. J. Exp. Mar. Biol. Ecol. 72, 125-145. 
Aksnes, D.L., Miller, C.B, Ohman, M.D., Wood, S.N., 1997. Estimation techniques used in studies of copepod population dynamics - a review of underlying assumptions. Sarsia 82, 279-296.

Ambler, J.W., 1985. Seasonal factors affecting egg production and viability of eggs of Acartia tonsa Dana from East Lagoon, Galveston, Texas. Estuarine Coast Shelf Sci. 20, 743-760.

Bernard, M., 1971. La forme elliptique de la relation température-durée de développement embryonnaire chez les copépodes pélagiques et ses proprietés. In: Crisp, D.J. (Ed.), 4th Eur. Mar. Biol. Symp. (Cambridge), pp. $203-209$

Burdon, R.H., 1987. Thermotolerance and the heat shock proteins. In: Bowler, K., Fuller, B.J. (Eds.), Temperature and Animal Cells. Symposia of the Society of Experimental Biology, vol. 41, pp. 269-283.

Carlotti, F., Nival, S., 1991. Individual variability of development in laboratory reared Temora stylifera copepodites: consequences for the population dynamics and interpretation in the scope of growth and development rules. J. Plankton Res. 13 (4), 801-813.

Colebrook, J.M., 1964. Continuous Plankton Records: a principal component analysis of the geographical distribution of zooplankton. Bull. Mar. Ecol. 6, 78-100.

Conover, R.J., 1988. Comparative life histories in the genera Calanus and Neocalanus in high latitudes of the northern hemisphere. Hydrobiologia 167-168, 127-142.

Corkett, C.J., 1972. Development rate of copepod eggs of the genus Calanus. J. Exp. Mar. Biol. Ecol. 10, 171 - 175.

Corkett, C.J., McLaren, I.A., 1970. Relationship between development rate of eggs and older stages of copepods. J. Mar. Biol. Assoc. U. K. 50, 161-168.

Corkett, C.J., Mc Laren, I.A., 1984. The rearing of the marine calanoid copepods Calanus finmarchicus (Gunnerus), C. glacialis (Jaschnov) and C. hyperboreus (Krøyer) with comment on the equiproportional rule. In: Schriever, G., Schminke, H.K., Shih, C.T. (Eds.), Proceedings of the 2nd Int. Conference on Copepoda, Ottawa. Syllogeus, vol. 58, pp. 539-546.

Corkett, C.J., Zilioux, E.J., 1975. Studies on the effect of temperature on the egg laying of three species of calanpod copepods in the laboratory, Acartia tonsa, Temora longicornis and Pseudocalanus elongatus. Bull. Plankton Soc. Jpn. 21 (2), 13-21.

Dahlhoff, E.P., Rank, N.E., 2000. Functional and physiological consequences of genetic variation at phosphoglucose isomerase: heat shock protein expression is related to enzyme genotype in montane beetle. Proc. Natl. Acad. Sci. U. S. A. 10, 10056-10061.

Fransz, H.G., Colebrook, J.M., Gamble, J.C., Krause, M., 1991. The zooplankton of the North Sea. Neth. J. Sea Res. $28(1 / 2), 1-52$.

Fryd, M., Haslund, O.H., Wohlgemuth, O., 1991. Development, growth and egg production of the two copepod species Centropages hamatus and Centropages typicus in the laboratory. J. Plankton Res. 13 (4), 683-689.

Fujisawa, H., 1995. Variation in embryonic temperature sensitivity among groups of the sea urchin, Hemicentrotus pulcherrimus, which differ in their habitats. Zool. Sci. 12 (5), 583-589.

Gaudy, R., 1976. Etude du plancton de la zone nord de la rade de Villefranche à la fin du printemps: III. Production secondaire des copépodes pélagiques. Vie Milieu, Ser. B 26, 77-106.

Gaudy, R., Cervetto, G., Pagano, M., 2000. Comparison of the metabolism of Acartia clausi and A. tonsa: influence of temperature and salinity. J. Exp. Mar. Biol. Ecol. 147 (1), 51-65.

Giesbrecht, W., 1892. Systematik und Faunistik der pelagischen Copepoden des Golfes von Neapel und der angrenzenden Meeres-Abschnitte Verlag Friedländer and Sohn, Berlin.

Gilat, E., Kane, J.E., Martin, J., 1965. Study of an ecosystem in the coastal waters of the Ligurian Sea. II. Surface zooplankton. Bull. Inst. Oceanogr. (Monaco) 65, 1-56.

Grant, G.C., 1988. Seasonal occurrence and dominance of Centropages congeners in the Middle Atlantic Bight, USA. Hydrobiologia 167/168, 227-237.

Halsband, C., Hirche, H.-J., 2001. Reproductive cycles of dominant calanoid copepods in the North Sea. Mar. Ecol.: Prog. Ser. 209, 219-229.

Halsband, C., Hirche, H.-J., 2001. Reproductive cycles of dominant calanoid copepods in the North Sea. Mar. Ecol.: Prog. Ser. 209, 219-229.

Halsband-Lenk, C., Nival, S., Carlotti, F., Hirche, H.-J., 2001. Seasonal cycles of egg production of two planktonic copepods, Centropages typicus and Temora stylifera, in the north-western Mediterranean. J. Plankton Res. 23 (6), 597-609. 
Hart, R.C., McLaren, I.A., 1978. Temperature acclimation and other influences on embryonic duration in the copepod Pseudocalanus sp. Mar. Biol. 45, 23-30.

Harris, R.P., Paffenhöfer, G.-A., 1976. Feeding, growth and reproduction of the marine planktonic copepod Temora longicornis Müller. J. Mar. Biol. Assoc. U. K. 56, 675-690.

Hofmann, G.E., 1999. Ecologically relevant variation in induction and function of heat shock proteins in marine organisms. Am. Zool. 39 (6), 889-900.

Hummel, H., Sommer, A., Bogaards, R., Pörtner, H.O., 1997. Variation in genetic traits of the lugworm Arenicola marina: temperature related expression of mitochondrial allozymes? Mar. Ecol.: Prog. Ser. 159, 189-195.

Huntley, M.E., Lopez, M.D.G., 1992. Temperature-dependent production of marine copepods: a global synthesis. The American Naturalist 140 (2), $201-242$.

Ianora, A., Buttino, I., 1990. Seasonal cycles in population abundances and egg production rates in the planktonic copepods Centropages typicus and Acartia clausi. J. Plankton Res. 12, 473-481.

Jashnov, W.A., 1970. Distribution of Calanus species in the northern hemisphere. Int. Rev. Gesamten Hydrobiol. $55,197-212$.

Jespersen, P., 1940. Non-parasitic copepoda. The Zoology of Iceland 3, 1-116.

Jónasdóttir, S.H., 1994. Effects of food quality on the reproductive success of Acartia tonsa and Acartia hudsonica: laboratory observations. Mar. Biol. 121, 67-81.

Kinne, O., 1963. The effects of temperature and salinity on marine and brackish water animals: I. Temperature. Oceanogr. Mar. Biol. Ann. Rev. 1, 301-340.

Kiørbœ, T., Sabatini, M., 1995. Scaling of fecundity, growth and development in marine planktonic copepods. Mar. Ecol.: Prog. Ser. 120, 285-298.

Kiørbœ, T., Møhlenburg, F., Riisgård, H.U., 1985. In Situ Feeding Rates of Planktonic Copepods: A Comparison of Four Methods. J. Exp. Mar. Biol. Ecol. 88 (1), 67-81.

Kimoto, K., Uye, S., Onbé, T., 1986. Egg production of a brackish-water calanoid copepod Sinocalanus tenellus in relation to food abundance and temperature. Bull. Plankton Soc. Jpn. 33, 133-145.

Klein Breteler, W.C.M., Gonzales, S.R., 1986. Culture and development of Temora longicornis, Copepoda Calanoida, at different conditions of temperature and food. Syllogeus 58, 71-84.

Klein Breteler, W.C.M., Schogt, N., van der Meer, J., 1994. The duration of copepod life stages estimated from stage frequency data. J. Plankton Res. 16 (8), 1039-1057.

Klekowski, R.Z., Weslawski, J.M., 1990. Atlas of the marine fauna of southern Spitsbergen. Invertebrates part 1, vol. II, pp. 97-103.

Krause, M., Dippner, J.W., Beil, J., 1995. A review of hydrographic controls on the distribution of zooplankton biomass and species in the North Sea with particular reference to a survey conducted in January-March 1987. Prog. Oceanogr. 35, 81-152.

Landry, M.R., 1975. Seasonal temperature effects and predicting development rates of marine copepod eggs. Limnol. Oceanogr. 20, 434-440.

Landry, M.R., 1983. The development of marine calanoid copepods with comment on the isochronal rule. Limnol. Oceanogr. 28 (4), 614-624.

Lawson, T.J., Grice, G.D., 1970. The developmental stages of Centropages typicus Krøyer, Copepoda, Calanoida. Crustaceana 18 (2), 187-208.

Le Ruyet-Person, J., Razouls, C., Razouls, S., 1975. Biologie comparée entre espèces vicariantes et communes de copépodes dans un écosystème néritique en Méditerranée et en Manche. Vie Milieu 25 (2), $283-312$.

Lindau, R., 2001. Climate Atlas of the Atlantic Ocean Springer Verlag, Berlin, 514 pp.

Lindley, J.A., 1986. Dormant eggs of calanoid copepods in sea-bed sediments of the English Channel and southern North Sea. J. Plankton Res. 8, 399-400.

Lindley, J.A., 1990. Distribution of overwintering calanoid copepod eggs in seabed sediments around southern Britain. Mar. Biol. 104, 209-217.

Lonsdale, D.J., Levinton, J.S., 1985. Latitudinal differentiation in embryonic duration, egg size, and newborn survival in a harpacticoid copepod. Biol. Bull. 168, 419-431.

Marcus, N.H., 1989. Abundance in bottom sediments and hatching requirements of eggs of Centropages hamatus (Copepoda: Calanoida) from the Alligator Harbor Region, Florida. Biol. Bull. 176, 142-146.

Marcus, N.H., 1996. Ecological and evolutionary significance of resting eggs in marine copepods: past, present, and future studies. Hydrobiologia 320, 141-152. 
McLaren, I.A., 1966. Predicting development rate of copepod eggs. Biol. Bull. Mar. Biol. Lab., Woods Hole 131, 457-469.

McLaren, I.A., 1978. Generation lengths of some temperate marine copepods: estimation, prediction, and implications. J. Fish. Res. Board Can. 35, 1330-1342.

McLaren, I.A., Corkett, C.J., Zilioux, E.J., 1969. Temperature adaptations of copepod eggs from the Arctic to the Tropics. Biol. Bull. Mar. Biol. Lab., Woods Hole 137, 486-493.

McLaren, I.A., Tremblay, M.J., Corkett, C.J., Roff, J.C., 1989. Copepod production on the Scotian Shelf based on life-history analysis and laboratory rearings. Can. J. Aquat. Sci. 46, 560-583.

Mori, T., 1964. The Pelagic Copepoda from the Neighbouring Waters of Japan Soyo, Tokyo, $150 \mathrm{pp}$.

Nassogne, A., 1972. Etudes préliminaires du zooplankton dans la constitution et le transfert de la matière organique au sein de la chaîne alimentaire marine en Mer Ligure. Radioattiva del mare. Fiascherino, La Spezia, CNEN. Laboratorio por lo studio della contaminazione. PhD dissertation.

Nival, P., Nival, S., 1976. Particle retention efficiencies of an herbivorous copepod Acartia clausi (adult and copepodite stages): effects on grazing. Limnol. Oceanogr. 21, 24-38.

Ohman, M.D., 1986. Predator-limited population growth of the copepod Pseudocalanus sp. J. Plankton Res. 8, $673-713$.

Ohman, M.D., 1990. The demographic benefits of diel vertical migration by zooplankton. Ecol. Monogr. 60, 257-268.

Pedersen, G., Tande, K.S., 1992. Physiological plasticity to temperature in Calanus finmarchicus. Reality or artefact? J. Exp. Mar. Biol. Ecol. 155, 183-197.

Pertzova, N.M., 1974. Life cycle and ecology of a thermophilus copepod Centropages hamatus in the White Sea. Zool. Zh. 52, 1013-1022, in Russian.

Peterson, W.T., Kimmerer, W.J., 1995. Processes controlling recruitment of the marine calanoid copepod Temora longicornis in Long Island Sound: egg production, egg mortality, and cohort survival analysis. Limnol. Oceanogr. 39, 1594-1605.

Planque, B., Fromentin, J.-M., 1996. Calanus and environment in the eastern North Atlantic. 1. Spatial and temporal patterns of $C$. finmarchicus and C. helgolandicus. Mar. Ecol.: Prog. Ser. 134 (1-3), 101-109.

Pörtner, H.O., 2001. Climate change and temperature-dependent biogeography: oxygen limitation of thermal tolerance in animals. Naturwissenschaften 88, 137-146.

Razouls, C., 1974. Variations annuelles quantitatives de deux espèces dominantes de copépodes planctoniques Centropages typicus et Temora stylifera de la région de Banyuls: cycles biologiques et estimations de la production. III. Dynamique des populations et calcul de leur production. Cah. Biol. Mar. 15, 5188.

Roe, H.S.J., 1972. The vertical distributions and diurnal migrations of calanoid copepods collected on the Sond cruise, 1965. 3. Systematic account: Families Euchaetidae up to and including Metridiidae. J. Mar. Biol. Assoc. U. K. 52, 525-552.

Rose, M., 1933. Copépodes pélagiques. In: Le Chevalier, R.G. (Ed.), Faune de France, vol. 26, pp. $170-184$.

Rose, M., 1957. Copépodes pélagiques. In: Le Chevalier, M. (Ed.), Faune de France, vol. 26, pp. $170-184$.

Salonen, K., 1979. A versatile method for rapid and accurate determination of carbon by high temperature combustion. Limnol. Oceanogr. 24, 177-185.

Sars, G.O., 1928. An account of the Crustacea of Norway. IV. Copepoda calanoida. Chritiana Alb. Cammermeyer's Forlag Bergen, $171 \mathrm{pp}$.

Scott, T., 1911. Résumée des observationssur le plancton des mers explorées par le conseil pendant les années 1902 - 1908. Copepoda (part.). Bulletin Trimestriel du Conseil Permanent International Pour L'Exploration de la Mer ICES Journal du Conseil 1911, 106-149.

Smith, S.L., Lane, P.V.Z., 1985. Laboratory studies of the marine copepod Centropages typicus: egg production and development rates. Mar. Biol. 85, 153-162.

Sullivan, B.K., McManus, L.T., 1986. Factors controlling seasonal succession of the copepods Acartia hudsonica and A. tonsa in Narragansett Bay, Rhode Island: temperature and resting egg production. Mar. Ecol.: Prog. Ser. $28,121-128$.

Tanskanen, S., 1994. Seasonal variability in the individual carbon content of the calanoid copepod Acartia bifilosa from the northern Baltic Sea. Hydrobiologia 292/293, 397-403.

Tester, P.A., 1982. The effects of the temperature acclimation of parental generations and incubation temperature 
on lability of egg hatching time in the copepod Acartia tonsa Dana. PhD dissertation. Oregon State University, $53 \mathrm{pp}$.

Uye, S., 1981. Fecundity studies of neritic calanoid copepods Acartia clausi Giesbrecht and A. steueri Smirnov: a simple empirical model of daily egg production. J. Exp. Mar. Biol. Ecol. 50, 255-271.

van der Spoel, S., Heyman, R.P., 1983. A Comparative Atlas of Zooplankton. Springer Verlag, Berlin.

van Rijswijk, P., Bakker, C., Vink, M., 1989. Daily fecundity of Temora longicornis, Copepoda, Calanoida in the Oosterschelde estuary, SW Netherlands. Neth. J. Sea Res. 23, 293-303.

Vidal, J., 1980. Physioecology of zooplankton: II. Effects of phytoplankton concentration, temperature, and body size on the development and molting rates of Calanus pacificus and Pseudocalanus sp. Mar. Biol. 56, 135146.

Williams, R., 1985. Vertical distribution of Calanus finmarchicus and C. helgolandicus in relation to the development of the seasonal thermocline in the Celtic Sea. Mar. Biol. 86, 145-149. 